\title{
Research Methods for Reduced-Impact Logging: WORKSHOP RESULTS
}

F. E. Putz, Elias, P. Sist, D. P. Dykstra and R. Heinrich EDITORS

A report on the

\section{International Training Seminar on Reduced-I mpact Timber Harvesting and Natural Forest Management}

which was held 14-27 J uly 1996

in Bogor and East Kalimantan, Indonesia

organized by CIFOR and sponsored jointly with:

the US Agency for International Development the Forest Service, US Department of Agriculture the Food and Agriculture Organization of the United Nations
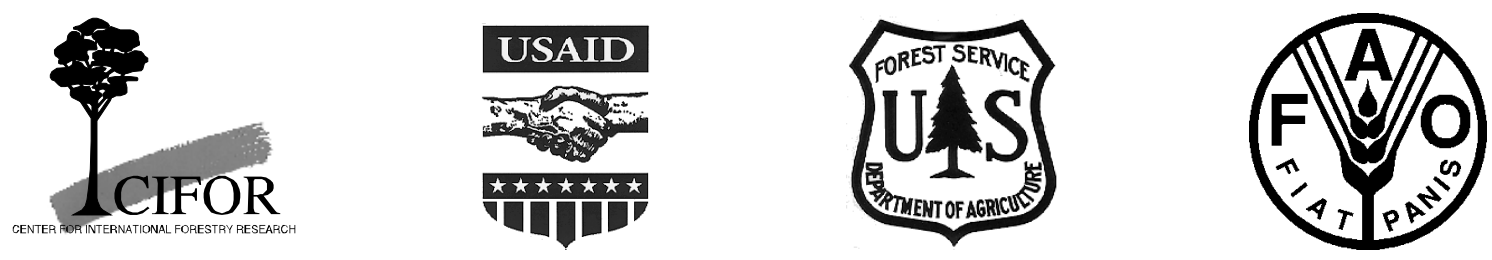
Copyright (C) 1996 Center for International Forestry Research

ISBN: 979-8764-11-0

Printed in Indonesia

Center for International Forestry Research (CIFOR)

P.O. Box 6596 JKPWB

Jakarta 10065, Indonesia

Fax

+62 251346433 or +62251622100

E-mail cifor@cgnet.com

World Wide Web http://www.cgiar.org/cifor 


\section{Preface}

A major milestone on the road towards sustainable forest management would be reached if the environmental impacts associated with timber harvesting operations could be substantially reduced. The development and implementation of environmentally sound harvesting practices, an important first step along this road, requires a sound basis in research. All phases of reduced-impact logging must be investigated from ecological, silvicultural, sociological, financial, and economic perspectives. For example, what are the financial costs and silvicultural benefits of preplanning skid trails? What sort of training and incentive programs are most likely to promote directional felling? How do different tree species respond to bark removal and other sorts of logging damage? Where should streamside buffer zones be located to most effectively reduce stream sediment loads after logging? These are just some examples of researchable issues that this workshop was designed to support.

With assistance from FAO, USAID, and the USDA Forest Service, CIFOR was pleased to offer its first International Research Training Seminar on Reduced-Impact Timber Harvesting and Natural Forest Management from July 14-27, 1996 in Bogor and East Kalimantan, Indonesia.

The 17 participants in the workshop (Appendix 1) were drawn from ten countries and represented disciplines ranging from silviculture and hydrology to wildlife biology. Seven were from national research institutes, five from universities, four from the private sector, and one from a government forest management agency. Although the focus of the workshop was on Southeast Asia, one scientists each from Africa and Latin America was included in order to build expertise for future workshops in those regions. The rather heavy course schedule (Appendix 3 ) and a wealth of reading materials (Appendix 4) tested the talents and time-management skills of all the participants as well as the instructors.

Throughout the workshop, field exercises were integrated with classroom activities, initially in the experimental forest plantation near CIFOR's new headquarters building and later at an industrial timber concession in East Kalimantan. The workshop began with an intensive review of statistics and experimental design, complemented by brief field projects on factors influencing rates of soil water infiltration. The results of these projects were analyzed with the aid of statistical software, and each student gave a short presentation on the experiment and its outcome. Further lectures, discussions, and problem sets on topics related to timber harvesting and the measurement of its impacts were reinforced by a three-day visit to an industrial timber concession near Balikpapan, East Kalimantan. During this period each participant planned and carried out a one-day research project on some aspect of forest management. This allowed the participants to individually develop testable hypotheses, design appropriate field research methods, collect data, carry out statistical analyses, and present the results both orally and in a written report prepared with word-processing software. The participants' written reports constitute the bulk of this publication.

In reading this volume it should be kept in mind that each research project was carried out in less than one day, with limited equipment, and using assistance only such as the participants could provide each other. The data analysis and write- 
up phases were also brief, but we hope that the reports are indicative of the hard work and creative energy brought to the workshop by the participants.

The participants' reports have been grouped by subject matter so that they complement one another. The first group comprises seven papers concerned with soil compaction and erosion, and the second group consists of ten papers, one on tree damage and the remainder on the density or growth of trees occurring in different situations and under different conditions. Four of the papers in the latter group are concerned specifically with trees of the genus Macaranga, light-demanding pioneers which may quickly colonize areas opened by logging. For consistency of presentation the participants were asked to prepare their reports using the format of the Journal of Tropical Forest Science.

Altogether, we believe this was an excellent workshop, and that the participants carried away with them some of the enthusiasm for research, and its potential for solving problems in tropical forestry, which characterises the work being undertaken at CIFOR. We look forward to future workshops of this type.

\section{Acknowledgments}

Inevitably an international training workshop requires an enormous organizational effort. This is especially true when the participants come from many different countries for which the host country has a variety of visa requirements and in which airline scheduling may be difficult. We want particularly to recognize the efforts of Ms. Lia Wan, CIFOR Travel and Conference Coordinator, and Mrs. Nani Djoko, CIFOR Research Division Secretary. Also, the assistance of Mr. Yahyah Sampurna, CIFOR computer services technician, was essential for the smooth operation of the computer-based instruction and lab exercises. We are also grateful to the entire staff of CIFOR's Administration and Finance Division for their hard work in arranging payments and requisitions, often on short notice. For serving as a field laboratory and providing us a place to stay and do our research in East Kalimantan we want to thank the staff and officers of PT. ITCI (International Timber Corporation Indonesia). Finally, of course, we want to recognize the outstanding contributions of the workshop instructors (Appendix 1), many of whom prepared written lecture notes and exercise materials. Without their expertise and enthusiasm the course would not have been possible.

Francis E. Putz

CIFOR Senior Associate

Workshop Coordinator and

Lead Instructor
Dennis P. Dykstra

Deputy Director General-Research

Workshop Organizer 


\section{Table of Contents}

Francis E. Putz Soil compaction and water infiltration: overview of group projects

Muhammad Water infiltration rates on a skidtrail and in adjacent residual

Farid A.R. forest 20 years after logging in East Kalimantan, Indonesia

Mohd. Daud Effect of wood extraction by crawler tractors on infiltration rates

Tampokong on a skidtrail 20 years after logging in East Kalimantan, Indonesia

Ohn Winn Effect of skidtrail slope on infiltration rates in a forest logged 20 years ago in East Kalimantan, Indonesia

Herman

Soil loss in relation to skidtrail slopes 20 years after selective

Prayudi logging in East Kalimantan, Indonesia

Lopachoke The effect of skidtrail curves on soil loss in a selectively

Thawornwong harvested dipterocarp forest in East Kalimantan, Indonesia

Mai Van

Thanh

Charles

Dei-Amoah

Dar-Hsiung

Wang

Tin Tun

Lorentz

Marpaung

A. Suyana
Influence of slope and distance from ridgetops on soil erosion from skidtrails 20 years after logging in East Kalimantan, Indonesia

Natural regeneration on skidtrails 20 years after logging in East

Kalimantan, Indonesia

Indonesia

Basal areas of pioneer and primary trees 20 years after logging in East Kalimantan, Indonesia

Slope influence on tree density 20 years after logging in East

Kalimantan, Indonesia

Dipterocarp seedling densities adjacent to a skidtrail and in residual forest 20 years after logging in East Kalimantan, Indonesia 
Rudy A. Relation between tree density and maximum diameter of

Guzmán Macaranga trees in different size gaps 20 years after logging in

Gutíerrez East Kalimantan, Indonesia

Priscila Effect of nearest neighboor tree species on Macaranga diameter

Dolom in a logged forest in Indonesia

Ahmad Tree seedling densities under patches of Macaranga and under

Budiaman other tree species 20 years after logging

R.P. Escobin Macaranga tree density variation in felling gaps in logged-over forest in East Kalimantan, Indonesia

Elizabeth A. Effects of disturbance on plant functional attributes in a logged

Zweede forest in Borneo: photosynthetic stems and level of furcation

Ismoyo

Influence of neighbour trees on the diameter of focal trees in logged-over dipterocarp forest, East Kalimantan, Indonesia

Francis E. Putz Logging time studies: overview of group projects 65 and

Rudolf Heinrich

Appendix 1 Alphabetical list of participants

Appendix $2 \quad$ Alphabetical list of instructors

Appendix 3 Workshop schedule 73

Appendix 4 List of distributed materials 77 


\title{
SOIL COMPACTION AND WATER INFILTRATION: OVERVIEW OF GROUP PROJECTS
}

\author{
Francis E. Putz \\ Center for International Forestry Research (CIFOR), Bogor, Indonesia
}

\section{Introduction}

Soil damage is a serious problem in forest management areas, particularly where ground-based timber yarding methods are utilized. Vehicular traffic unavoidably results in soil compaction, increased bulk density, decreased pore space, decreased water infiltration rates, and increased runoff. Plants do not grow well in compacted soil, primarily due to mechanical impedence of root growth which limits their access to nutrients. Where soil compaction is severe, roots can be subjected to anaerobic conditions, which further limits their nutrient uptake and growth rates. To explore some of these and other issues related to soil damage, we conducted group projects in a plantation near the new CIFOR Headquarters in the Darmaga community of Bogor, Indonesia. In addition to learning more about soils and hydrology, the projects were intended to help the participants with the following:

- hypothesis formulation,

- experimental design,

- sampling methods,

- sample size determination,

- statistical analysis, and

- oral presentation of research results.

\section{Methods}

To measure water infiltration rates, each participant was provided with a $7.6 \mathrm{~cm}$ diameter, $13.5 \mathrm{~cm}$ long PVC tube sharpened at one end. After a tube was driven $1.5 \mathrm{~cm}$ into the ground, it was filled with water and the rate of water drainage was measured for 30 to 120 seconds. Infiltration rate is expressed as $\mathrm{mm} / \mathrm{minute}$. The infiltrometers and methods used are not exactly those used by hydrologists and soil physicists, but the data nevertheless provide a relative measure of infiltration rates.

Determination of the sample sizes needed to distinguish between hypotheses require some knowledge about the variability in the data to be collected. To estimate variance in soil infiltration rates we conducted a pilot study. The participants and several resource people each measured infiltration rates at 1 or 2 randomly located points in an Agathis stand in the Darmaga plantation. The data $(\mathrm{N}=21)$ were then plotted in the field as running means. By inspection of the plot of running means, we decided that a sample size of 15 would be sufficient for the purposes of the group 
studies to follow (i.e., the variance appeared to settle down satisfactorily after sample sizes of 13 or 14 had been obtained).

The group projects on infiltration rates carried out on the morning of 16 July included tests of the following hypotheses:

1. Soil infiltration rates are slower on forest trails than in the adjacent plantations where there is little pedestrian traffic.

2. Soil infiltration rates differ at the soil surface $(0 \mathrm{~cm}), 5 \mathrm{~cm}$, and $10 \mathrm{~cm}$.

3. Trampling (i.e., foot traffic) reduces soil infiltration rates but the effect is less on soil with an intact litter layer than in areas from which the litter was experimentally removed.

4. Soil infiltration rates differ on forest trails, in forest plantations, and in young stands of Calliandra.

5. Infiltration rates differ under canopy gaps and under planted Agathis trees.

The results of these studies were presented orally in the afternoon by a representative of each group. The statistical analysis and data manipulations used included the following:

- Logarithmic transformations

- Student's t-tests

- Mann-Whitney U-tests

- Analysis of variance followed by pairwise comparisons (t-tests)

- Kruskal-Wallis tests followed by pairwise comparisons (Mann-Whitney U-tests).

The data were also used in estimations of power and determination of sample sizes needed at different probability levels for Type I (alpha) and Type II (beta) errors (i.e., false rejection of a true null hypothesis and failure to reject a false null hypothesis, respectively).

Overall the experience seemed very successful. The participants reported that they learned a great deal about soil, sampling, and data presentations. The speakers were given feedback on how to make their presentations more effective. The experimental (i.e., manipulative) studies were more revealing and more interesting than the correlative studies (that is, hypotheses 1, 4 and 5 above). In future exercises it would be advisable to encourage all participants to develop and test hypotheses involving direct manipulation. Perhaps the issue of causation versus correlation should be more thoroughly discussed before deciding on the hypotheses to be tested. 


\title{
WATER INFILTRATION RATES ON A SKIDTRAIL AND IN ADJACENT RESIDUAL FOREST 20 YEARS AFTER LOGGING IN EAST KALIMANTAN, INDONESIA
}

\author{
Muhammad Farid A.R.
}

Forest Research Institute Malaysia, Kepong, 52109 Kuala Lumpur, Malaysia

\begin{abstract}
MUHAMMAD FARID A.R. 1996. Water infiltration rates on a skidtrail and in adjacent residual forest 20-years after logging in East Kalimantan, Indonesia. Even 20 years after logging, water infiltration rates on a skidtrail (mean $=6.1 \mathrm{~mm} / \mathrm{min}$ ) were significantly lower than in the adjacent residual forest (mean $=127.0 \mathrm{~mm} / \mathrm{min}$ ). Compaction and topsoil removal caused a decrease in macroporosity of the soil and consequently increased runoff from the skidtrail as compared to residual forest.
\end{abstract}

Key words: Water infiltration rate - skidtrail - residual forest - logging - compaction

\section{Introduction}

Impacts of logging on tropical forests has attracted the attention of many foresters and researchers, especially with the increased use of heavy machinery. Pinard et al. (1995) stated that uncontrolled logging results in excessive damage to the residual forest and reduces the forest's value for future timber production. Dykstra and Heinrich (1996) listed several common types of damages caused to forest ecosystems if proper attention is not given during log extraction. The damages include soil disturbance and soil compaction, stream sedimentation, and damage to residual trees and understory vegetation.

Several studies have been carried out that support the above statements. Lal (1987) found that forest clearance results in increased soil bulk density, while Chauval et al. (1991) reported that soil pore volume and infiltration rates decrease due to forest clearance. Dias and Nortcliff (1985) and Malmer and Grip (1990) reported that both soil type and moisture content during logging influence the degree of compaction.

To determine whether 20 years after logging soil conditions (macroporosity) on skidtrails recovers to typical forest conditions, I conducted a study on water infiltration rates in a logged-over forest in East Kalimantan.

\section{Study Area}

The study area is located the concession of International Timber Corporation Indonesia (ITCI; $1^{\circ} 16^{\prime} \mathrm{S}, 116^{\circ} 18^{\prime} \mathrm{E}$ ). The area was logged 20 years prior to this study. The estimated timber volume harvested in 1976 was 90 to $120 \mathrm{~m}^{3} / \mathrm{ha}$. The climate is equatorial with an annual rainfall of about 2000 to $2500 \mathrm{~mm}$. The bedrock is primarily alluvial deposits (mudstone, siltstone and sandstone) dating from the Miocene and Pliocene. The topography is gentle with elevations ranging from 230 to $300 \mathrm{~m}$ a.s.l. 


\section{Methods}

The following hypothesis was tested:

$\mathrm{H}_{\mathrm{a}}$ : Twenty years after logging, water infiltration rates on a skidtrail differ significantly from those in an adjacent residual forest.

The infiltrometers were made from a PVC pipe with a diameter of $7.6 \mathrm{~cm}$ and a height of $13.0 \mathrm{~cm}$. About $1.0 \mathrm{~cm}$ from the end, the pipes were sharpened to allow easy placement of the infiltrometer in the soil during sampling. A hammer was used to drive the infiltrometer $1 \mathrm{~cm}$ into the soil. Water was then poured into the infiltrometer and a stopwatch was used to measure drainage rate. Infiltration measurements were taken at random locations on a skidtrail and in the adjacent residual forest.

\section{Results}

Water infiltration rates in the residual forest (mean $=127 \mathrm{~mm} / \mathrm{min}, \mathrm{N}=22$ ) were be significantly faster than on the skidtrail (mean $=6.1 \mathrm{~mm} / \mathrm{min}, \mathrm{N}=22)(\mathrm{t}=11.63, \mathrm{P}<$ 0.001, Table 1).

\section{Discussion}

Log skidding using crawler tractors has great impacts on soil and vegetation. Once the topsoil, litter and vegetation are removed and the soil is compacted during skidtrail construction, soil pore volumes and water infiltration rates decrease. In addition, the number of passes of crawler tractors on the same skidtrail further influences the degree of compaction which in turn affects water infiltration rates. This claim is supported by Tampokong (1996) who investigated the influence of crawler tractors on water infiltration rates on a skidtrail in the same study site. He concluded that water infiltration rates are lower when the number of passes by the crawler tractor increases.

Loss of organic matter when topsoil is scraped away by bulldozers negatively affects plant growth. This effect is very important in the tropics where most soils are dominated by low-activity clays and organic matter is important not only as a source of nutrients, but also affects soil physical properties. Almost all skidtrails are exposed to erosion and in many instances only shrubs or grass will grow on them even decades after logging.

Forest managers should consider how to improve wood extraction operations, especially whether to continue to allow use of crawlers for log yarding or to look for alternative extraction systems. Other ground-based machines are available that have lower ground pressure (e.g., tracked skidders) which are able to maneuver on steep slopes but do less damage to soil than crawler tractors. 
Table 1. Results of water infiltration rate tests on a skidtrail and in the adjacent residual forest.

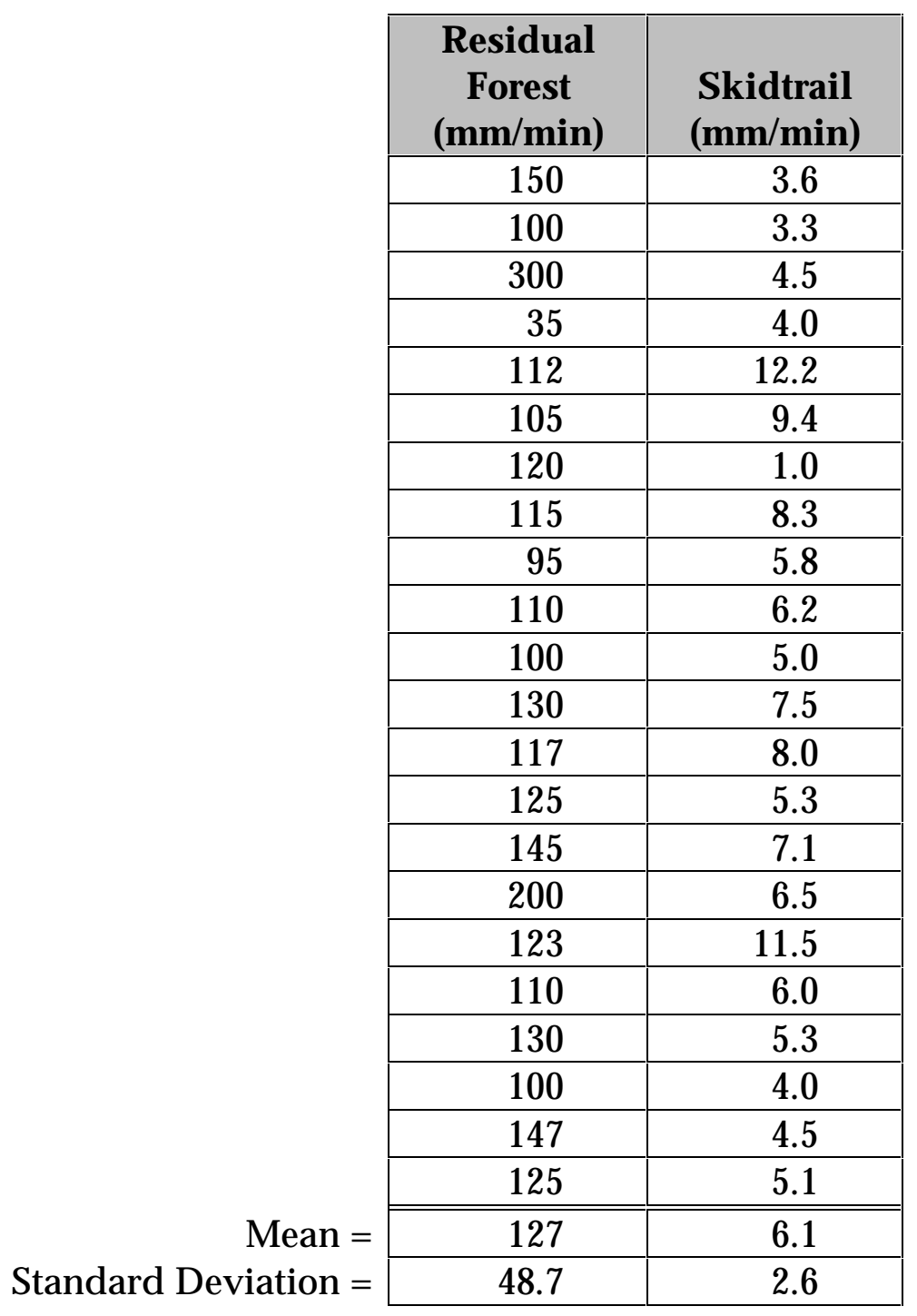

\section{Acknowledgments}

I am indebted to a number of people and organizations for making possible the completion of this study. To the International Timber Corporation Indonesia (ITCI), I extend my sincere thanks for the hospitality extended to me during this study. I am grateful to Francis E. Putz for motivating and inspiring me to take up this challenge. My sincere appreciation goes to Rudolf Heinrich of FAO and Dr. Ir. Elias (Bogor Agricultural University) for their guidance, discussion, assistance and the time they took to review earlier drafts of this paper. I also want to thank FAO for sponsoring my participation. Profound appreciation and thanks are extended to other instructors of this training seminar particularly Dennis P. Dykstra, Andrew Gillison, Plinio Sist, Ravi Prabhu and Leonard A. Newell. I extend my sincere thanks to Mrs. Nani Djoko and Ms. Lia Wan for helping to me in such a comfortable situation during my stay in Bogor. 


\section{Reference}

Chauvel,A., M. Grimaldi, and D. Tessier. 1991. Changes in soil pore-space distribution following deforestation and revegetation: An example from the Central Amazon Basin, Brazil. For. Ecol. and Mgmt. 38:259-271.

Dias, A.C.C.P., and S. Nortcliff. 1985. Effects of tractor passes on the physical properties of an oxisol in the Brasilian Amazon. Trop. Agri. (Trinidad) 62:207-212.

Dykstra, D.P. and R. Heinrich. 1996. FAO Model Code of Forest Harvesting Practice. Food and Agriculture Organization of the United Nations, Rome. 85 p.

Lal, R. 1987. Tropical Ecology and Physical Edaphology. Wiley, London.

Malmer,A., and H. Grip. 1990. Soil disturbance and loss of infiltrability caused by mechanized and manual extraction of tropical rainforest in Sabah, Malaysia. For. Ecol. and Mgmt. 38: 1-12.

Tampokong, M.D. 1996. Effect of wood extraction by crawler tractors on infiltration rates on a skidtrail 20 years after logging in East Kalimantan, Indonesia. In: Research Methods for Reduced-Impact Logging: Workshop Results. F.E.Putz, Elias, P.Sist. D. Dykstra, and R. Heinrich, editors. CIFOR Special Publication. 


\title{
EFFECT OF WOOD EXTRACTION BY CRAWLER TRACTORS ON INFILTRATION RATES ON A SKIDTRAIL 20 YEARS AFTER LOGGING IN EAST KALIMANTAN, INDONESIA
}

\author{
Mohd. Daud Tampokong \\ Yayasan Sabah (Innoprise Corporation Sdn. Bhd.), 91017 Tawau, Sabah, Malaysia.
}

\begin{abstract}
TAMPOKONG, M. D. 1996. Effect of wood extraction by crawler tractors on infiltration rates on a skidtrail 20 years after logging in East Kalimantan, Indonesia. Water infiltration rates on a skidtrail 20 years after logging activities and its relation to the number of crawler tractor passes were investigated. The number of passes was estimated by ranking the sections on a skidtrail according to the number of feeder roads (branch skidtrail). Skidtrails were ranked into 3 categories, in which Rank 1 was from the end of the skidtrail to Branch 1, Rank 2 (Branch 1 to Branch 2), and Rank 3 (Branch 2 to Main Logging Road 2000). Generally, water infiltration rates on Rank 1 skidtrails were greater than on Rank 2 which in turn were greater than on Rank 3.
\end{abstract}

Key words: Water infiltration rate - crawler tractor passes - skidtrail - logging

\section{Introduction}

Crawler tractors are the most widely used machines for timber extraction in tropical forests. They are often used for road construction and maintenance as well as for skidding (Dykstra and Heinrich 1996). These heavy machines unavoidably alter soil physical properties during timber extraction. Woodward (1996) stated that timber extraction with heavy machines causes soil compaction, resulting in reduced water infiltration rates and increased runoff. Blading skidtrails unnecessarily by tractor operators also is a major problem in many forests (Dykstra and Heinrich 1996).

\section{Study Area}

This study was conducted in the International Timber Corporation Indonesia (ITCI) concession area in East Kalimantan, Indonesia $\left(1^{\circ} 16^{\prime} \mathrm{S}, 116^{\circ} 18^{\prime} \mathrm{E}\right)$. The study area was logged in 1976 by Weyerhauser Corporation. The general elevation of the area ranges between 230 to $300 \mathrm{~m}$ a.s.l. with mean annual precipitation of 2000 to 2500 $\mathrm{mm}$.

\section{Methods}

The following hypothesis was tested: Twenty years after logging, water infiltration rates on skidtrails are lower on sections of skidtrail that experienced a larger number of crawler tractor passes. 


\section{Equipment}

The data were collected by using an infiltrometer made from PVC pipe with a diameter of $7.6 \mathrm{~cm}$ and length of $13 \mathrm{~cm}$ with one end sharpened. A ruler and stop watch were used to measure the rate of water infiltration $(\mathrm{mm} / \mathrm{min})$. A small hammer was also used to ensure that the infiltrometer was firmly inserted $1.0 \mathrm{~cm}$ into the soil.

\section{Skidtrail ranking and establishment of measurement points}

Skidtrails were ranked on the basis of the relative number of crawler tractor passes which was in turn was based on the number of branch skidtrails that were found along the main skidtrail. Ranks increase with the number of branch skidtrails. In other words, Rank 1 with the least crawler tractor passes, was from the forest end of the skidtrail to Branch 1, Rank 2 was from Branch 1 to Branch 2, and Rank 3 from Branch 2 to the main logging road (Figure 1).

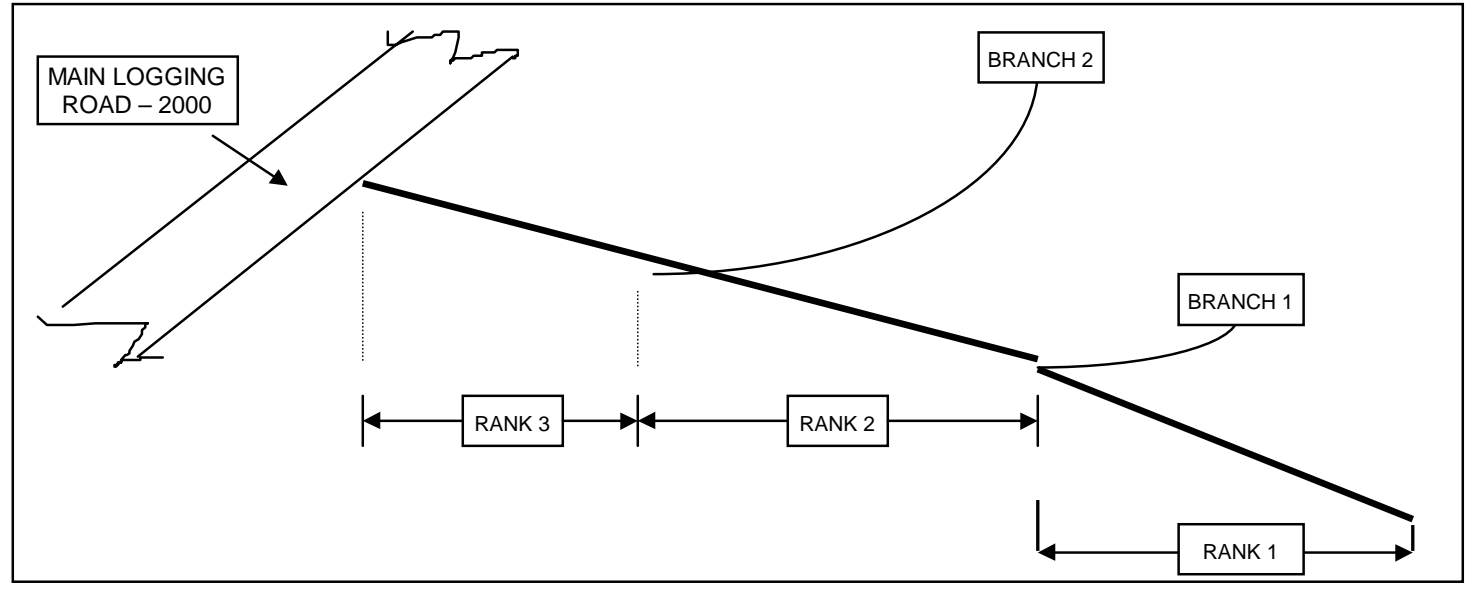

Figure 1. Sketch showing the method for ranking skidtrails on the basis of the relative number of crawler tractor passes.

Twenty infiltrometer readings were made at randomly located points along a skidtrail of each rank.

\section{Results}

Water infiltration rates were highest on skidtrails of Rank 1 (least number of passes) with a median value of $17.5 \mathrm{~mm} / \mathrm{min}$, and were significantly lower on skidtrails of Rank 2 (median = $3.5 \mathrm{~mm} / \mathrm{min}$ ), and Rank 3 (median=2.0 mm/min) (Kruskal-Wallis test, $\mathrm{P}<0.01)$. It can be concluded that the fewer crawler tractor passes on the skidtrail, the greater the water infiltration rates. 
Mann-Whitney U-Tests indicated that water infiltration rates differed among each rank ( $\mathrm{P}<0.01$ for all contrasts).

\section{Discussion}

The results of this study clearly demonstrate that the number of crawler tractor passes on skidtrails influences the rate of water infiltration even 20 years after logging. This finding was consistently supported by other scientists working at the same site (e.g., Muhammad Farid A. R. 1996, Ohn Winn 1996). These authors found that water infiltration rates in disturbed soil such as on skidtrails is less than that of undisturbed soil. The effects of crawler tractors on soils include reduced macropore space attributable to loss of topsoil and compaction, which reduces soil porosity and therefore water infiltration rates.

The use of crawler tractors for extraction substantially reduces the rates of water infiltration. Consequently, rain water is more likely to run along the surface of the skidtrails, resulting in soil erosion especially on skidtrails constructed on slopes. The use of equipment other than crawler tractors for timber extraction (e.g., rubbertyred skidders) can potentially reduce soil damage. In areas where crawler tractors must be employed, operators should be trained in good forestry practices. Close supervision of logging activities is also a must to ensure that the impacts of logging are effectively reduced.

\section{Acknowledgement}

I would like to take this opportunity to thank Drs. Rudolf Heinrich, Elias and Francis E. Putz for reviewing and commenting on earlier drafts of this paper. I also wish to thank all the instructors of this training seminar who have in one way or another helped me to understand and motivated me. To CIFOR, I convey my greatest gratitude for allowing me to participate in this very important training seminar. I wish to thank FAO for their sponsorship. To PT. ITCI concession, thank you for all the hospitality during our stay in East Kalimantan. Last but not least, to all fellow participants, I thank you for your moral support throughout the workshop.

\section{References}

Dykstra, D.P., Heinrich, R. 1996. FAO Model Code of Forest Harvesting Practice. Food and Agriculture Organization of the United Nations, Rome. 85p.

Muhammad Farid, A.R. 1996. Water infiltration rates on a skidtrail and adjacent residual forest 20 years after logging in East Kalimantan, Indonesia. In: Research Methods for Reduced-Impact Logging: Workshop Results. F.E. Putz, Elias, D. Dykstra, and R. Heinrich, editors. CIFOR Special Publication.

Ohn Winn. 1996. Effect of skidtrail slope on infiltration rates in a forest logged 20 years ago in East Kalimantan, Indonesia. In: Research Methods for Reduced-Impact Logging: Workshop Results. F.E. Putz, Elias, D. Dykstra, and R. Heinrich, editors. CIFOR Special Publication. 
Woodward, C.L. 1996. Soil compaction and top soil removal effects on soil properties and seedling growth in Amazonian Ecuador. Forest Ecology and Management 82: 197-209. 


\title{
EFFECT OF SKIDTRAIL SLOPE ON INFILTRATION RATES IN A FOREST LOGGED 20 YEARS AGO IN EAST KALIMANTAN, INDONESIA
}

\author{
Ohn Winn \\ Institute of Forestry, Yezin, Myanmar
}

\begin{abstract}
WINN, O. 1996. Effect of skidtrail slope on infiltration rates in a forest logged 20 years ago in East Kalimantan,Indonesia. Infiltration rates on slopes of $0-40 \%$ on a skidtrail and in adjacent residual forest 20 years after logging were investigated. There was a highly significant difference for different slope classes in both situations. The maximum infiltration rate was $2 \mathrm{~mm} / \mathrm{min}$ on the skidtrail and $212 \mathrm{~mm} / \mathrm{min}$ in the residual forest. Top soil with organic matter is scraped away by heavy machines during logging activies and soil compaction is enormously increased, thus causing lower infiltration rates. These effects apparently persist for at least 20 years.
\end{abstract}

Key words: Infiltration rate - skidtrail - compaction - logging - post harvest assessment - residual forest

\section{Introduction}

Use of heavy machines in dense tropical forests for logging disturbs soil, causes soil compaction, and increases the potential for erosion (Dykstra and Heinrich 1996, Lat et al. 1985, Nussbaum et al. 1995). Ewel and Conde (1980) supported the fact that uncontrolled logging of crop trees results in excessive damage to the residual forest and reduces the forest's value for future timber production. Woodward (1995) also confirmed that many soil physical and chemical properties are altered by soil compaction and topsoil removal. Chauval et al. 1991 reported that soil pore volumes and infiltration rates decrease due to forest clearance.

This study was carried out to determine whether infiltration rates recover to near normal conditions on skidtrails 20 years after logging on slopes of $0-40 \%$.

\section{Study Area}

The study area is in East Kalimantan, Indonesia, in the concession area of International Timber Corporation Indonesia (ITCI) $\left(1^{\circ} 16^{\prime} \mathrm{S}, 116^{\circ} 1^{\prime} \mathrm{E}\right)$. The area was logged 20 years prior to this study. The climate is equatorial with an annual rainfall of about $2000-2500 \mathrm{~mm}$ and maximum temperatures of $33^{\circ} \mathrm{C}$. Sist (1996) reported that the bedrock is primarily alluvial (mudstone, siltstone, and gravel) dating from the Miocene and Pliocene. The topography is gentle and undulating with elevations ranging from $230 \mathrm{~m}$ to $300 \mathrm{~m}$ a.s.l. 


\section{Methods}

Infiltration rates were sampled at random locations on slopes of $0-40 \%$ on the skidtrail and in the residual forest. Infiltrometers were made from $7.5 \mathrm{~cm}$ diameter PVC tubes inserted $1 \mathrm{~cm}$ into the soil.

\section{Results}

On slopes of $0-10 \%$, infiltration rates were extremely high in the residual forest (as much as $212 \mathrm{~mm} / \mathrm{min}$ ) but very low on the skidtrail (12 mm/min). On slopes of 10$20 \%$, the rates were still as high as $200 \mathrm{~mm} / \mathrm{min}$ in the residual forest but only $12 \mathrm{~mm} / \mathrm{min}$ on the skidtrail. Maximum infiltration rates on slopes of $20-30 \%$ were $84 \mathrm{~mm} / \mathrm{min}$ in residual forest but only $8 \mathrm{~mm} / \mathrm{min}$ on the skidtrail with the same slope. Infiltration rates as high as $24 \mathrm{~mm} / \mathrm{min}$ were observed in the residual forest on $30-40 \%$ slopes while they were only $2 \mathrm{~mm} / \mathrm{min}$ of the skidtrail on the same slope. These differences were all highly significant (t-test, $\mathrm{P}<0.001)$.

Simple linear regression between infiltration rates, and slope, were run separately on the skidtrails and in the residual forests on slopes of 0 to $40 \%$. The regressions of the skidtrail and residual forest data both had significant negative slopes with $\mathrm{R}^{2}$ values of 12.5 and $12.7 \%$ respectively.

\section{Discussion}

Even 20 years after logging, reductions in water infiltration rates into soil caused by crawler tractors were still very evident. Reductions in infiltration rates are particularly acute on steep slopes on skidtrails and in the residual forest.

\section{Conclusion}

Soil damage in tropical forest is extremely high during timber harvesting operations using heavy machines. Soil compaction reduces water availability, porosity and infiltration rates. Topsoil removal and the associated loss of nutrients may have an even greater negative effect than the drastic reductions of infiltration rate observed. Logging roads and skidtrails should be constucted by skilled engineers to mitigate destruction of soil, water and trees. Directional felling should also be adopted in timber harvesting operations to reduce the total number of skidtrails needed.

\section{Acknowledgements}

The author is indebted to Professor F.E. Putz, and Drs. R. Heinrich (FAO), D. Dykstra, P. Sist, and Elias as well as the staff of Center for International Forestry Research (CIFOR) and International Timber Corporation Indonesia for their kind assistance, understanding cooperation, and their comments on earlier drafts of this research paper. 


\section{References}

Chauvel, A., Grimaldi, M. and Tessier, D. 1991. Changes in pore-space distribution following deforestation and regeneration; and example from the Central Amazon Basin, Brazil. For. Ecol. Manage. 38: 259-271.

Dykstra, D.P. and Heinrich, R. 1995. FAO Model Code of Forest Harvesting Practice. Food and Agriculture Organization of the United Nations, Rome. 85 p.

Ewel, J. and Conde, L.F. 1980. Potential ecological impact of increased intensity of tropical forest utilization. BIOTROP Special Publication No. 11, Bogor, Java, Indonesia: SEAMEO Regional Center for Tropical Biology.

Lal, R. 1989. Tropical Ecology and Physical Edaphology. Wiley, London.

Nussbaum, R., Anderson, J. and Spencer, T. (In press). Factors limiting the growth of indigenous tree seedlings planted on degraded forest soils in Sabah, Malaysia. For. Ecol. and Mgt.

Woodward, C. 1995. Soil compaction and topsoil removal during mechanized clearing of tropical forest: effects on soil properties and seedling growth. Master's thesis, University of Florida, Gainesville, Florida, USA. 


\title{
SOIL LOSS IN RELATION TO SKIDTRAIL SLOPES 20 YEARS AFTER SELECTIVE LOGGING IN EAST KALIMANTAN, INDONESIA
}

\section{Herman Prayudi}

\author{
Association of Indonesian Forest Concession Holders (APHI), Jakarta, Indonesia
}

\begin{abstract}
PRAYUDI, H., 1996. Soil loss in relation to skidtrail slopes 20 years after selective logging in East Kalimantan, Indonesia. Logging operations have important effects on the environment, particularly on skidtrails. On skidtrails made by bulldozers, vegetation and litter is removed, and the soil is scraped and compacted. In this paper, soil loss in relation with skidtrail slope was assessed. The results indicated that soil loss rates were not affected by variation of skidtrail slopes.
\end{abstract}

Key Words: skidtrail - slope - logging operation - soil loss

\section{Introduction}

In Indonesia, most logging operations include crawler tractor ground skidding. The skidtrails are completely cleared of vegetation, litter and particularly top soil. During logging operations, top soil on the skidtrails is frequently pushed to one side by bulldozers (Gillman et al. 1985 in Nussbaum et al. 1995). The concentrations of organic matter on skidtrails is extremely low after logging (Nussbaum et al., 1995). Soil loss rates are also increased due to ground-based skidding, but the effect of skidtrail slope on erosion is not clear.

The Universal Soil-Loss Equation (USLE) predicts soil loss as a consequence of six factors (Young 1989):

1. The erosivity factor, which incorporates erosion related both to rainfall and to runoff.

2. The soil erodibility factor, describing the relative tendency of different soils to erode.

3. Slope steepness as compared to the slope of a standard erosion plot.

4. The slope length factor, which assesses the length of slope subject to erosion as compared to the length of a standard erosion plot.

5. The cover and management factor, which gives the ratio of soil loss from a specified ground cover and management system as compared to bare fallow.

6. The support practice factor, which is defined as the ratio of soil loss under a given conservation practice to that under crops in rows running up and down the slope. 
The objective of this study was to determine the relationship between soil loss rates from skidtrails and slope.

\section{Materials and methods}

\section{Site description}

The study was conducted in a logged-over area in a concession owned by PT. ITCI (International Timber Corporation Indonesia) located in East Kalimantan, Indonesia $\left(1^{\circ} 16^{\prime} \mathrm{S}, 116^{\circ} 18^{\prime} \mathrm{E}\right)$. This area was logged 20 years ago. Annual precipitation is 2000 $2500 \mathrm{~mm}$ and elevation ranges from 230 to $300 \mathrm{~m}$ a.s.l. The skidtrail was covered by seedlings, saplings and poles with some litter. The soil type is podsolic yellow and red clay. There was gully erosion on portions of the skidtrail.

\section{Methods}

Soil loss was assessed by making profile diagrams of skidtrails on different slopes. For each profile, a taut rope was stretched across the skidtrail and depths were measured at intervals of $20 \mathrm{~cm}$. Profiles were selected randomly and each skidtrail slope class was represented by three profiles. The distances between each profile and skidtrail slopes were recorded.

\section{Results}

To analyse the relationship between skidtrail slopes and soil loss I used linear regression. The regression equation tested was:

$$
\begin{aligned}
& Y=\beta_{0}+\beta_{1}(X) \\
& \text { where } Y=\log _{\mathrm{e}}\left(\text { cross-sectional soil loss in } \mathrm{m}^{2}\right) \\
& X=\text { skidtrail slope, in } \% \\
& \beta_{0}, \beta_{1}=\text { estimated regression parameters }
\end{aligned}
$$

The hypotheses tested were:

$\mathrm{H}_{0}$ : There is no relationship between skidtrail slopes and soil loss.

$\mathrm{H}_{\mathrm{a}}$ : A statistically significant relationship exists between skidtrail slopes and soil loss. 
Table 1. Skidtrail slopes and amounts of soil loss during 20 years of post-logging erosion.

\begin{tabular}{|c|c|c|}
\hline $\begin{array}{c}\text { Skidtrail } \\
\text { Width } \\
(\mathbf{m})\end{array}$ & $\begin{array}{c}\text { Slope } \\
(\mathbf{\%})\end{array}$ & $\begin{array}{c}\text { Soil Loss } \\
\mathbf{( m}^{\mathbf{2}} \mathbf{~}\end{array}$ \\
\hline 3.4 & 24 & 0.49 \\
\hline 3.6 & 24 & 0.47 \\
\hline 3.2 & 24 & 0.20 \\
\hline 3.9 & 35 & 0.40 \\
\hline 4.0 & 35 & 0.78 \\
\hline 4.4 & 35 & 1.06 \\
\hline 4.9 & 32 & 2.43 \\
\hline 4.3 & 32 & 1.12 \\
\hline 4.4 & 32 & 1.74 \\
\hline 5.2 & 17 & 1.41 \\
\hline 5.6 & 17 & 1.12 \\
\hline 5.7 & 17 & 1.70 \\
\hline 4.6 & 31 & 2.18 \\
\hline 4.4 & 31 & 1.88 \\
\hline 4.4 & 31 & 1.06 \\
\hline 3.5 & 9 & 9.46 \\
\hline 3.3 & 9 & 0.28 \\
\hline 3.7 & 9 & 0.57 \\
\hline 5.3 & 10 & 1.02 \\
\hline 5.2 & 10 & 0.91 \\
\hline 4.3 & 10 & 0.61 \\
\hline 4.3 & 12 & 1.07 \\
\hline 4.2 & 12 & 0.72 \\
\hline 4.0 & 12 & 0.52 \\
\hline & & \\
\hline
\end{tabular}

The results of data analysis using linear regression showed that the relationship between skidtrail slope and the natural logarithm of soil loss was not significant $(\mathrm{t}=$ $1.64, \mathrm{P}=0.114$ at $\mathrm{df}=22$ ). Therefore, there was no statistically significant relationship between skidtrail slope and soil loss.

\section{Discussion}

According to Young (1989), soil loss is linked to six factors (rainfall, soil erodibility, slope steepness, slope length, ground cover, and conservation practices). Harvesting equipment and experience of tractor operators may also influence rates of postlogging soil loss. This study considered only one factor, slope steepness. Other factors may have varied substantially among the sample plots selected for the research. 


\section{Conclusion}

There was no statistically significant relationship between skidtrail slope and soil loss rates from the skidtrail 20 years after selective logging. Many factors can influence soil loss rates in the logged-over forest area. Future studies should include factors in addition to slope, or should ensure that the other factors are held constant.

\section{Acknowledgements}

The author would like to thank CIFOR, FAO, USAID, and the USDA Forest Service for allowing him to participate in the International Seminar on Reduce-Impact Timber Harvesting and Natural Forest Management Research Methods. Special thanks to all Instructors who have motivated me to conduct this research. Thanks to management of PT.ITCI for accomodation and assistance in the field.

\section{References}

Dykstra, D.P. and R. Heinrich. 1996. FAO Model Code of Forest Harvesting Practice. Food and Agriculture Organization of the United Nations. 85 p.

Elias. 1996. Stand damage and regeneration in forest concession areas of PT. Kiani Lestari and PT. Narkata Rimba, East Kalimantan, Indonesia. CIFOR/FAO/ USAID/USDA-FS International Research Training Seminar on Reduced-Impact Timber Harvesting and Natural Forest Management, Bogor, Indonesia.

Nussbaum, R. et al. 1995. Effects of selecive logging on soil characteristics and growth of planted dipterocarp seedlings in Sabah. In: R.B. Primack and T.E. Lovejoy (eds.) Ecology, Conservation and Management of Southeast Asia Rainforest. Yale University Press, New Haven, Connecticut, USA.

Sist, P. 1996. Reduced impact logging trials in East Kalimantan (STREK Project): harvesting volumes and damage assessment. CIFOR/FAO/USAID/USDA-FS International Research Training Seminar on Reduced-Impact Timber Harvesting and Natural Forest Management. July 15-27, 1996. Bogor, Indonesia.

Smits, W.T.M, H. Prayudi. 1994. A new method for production of digitized tree position maps. AIFM International Conference on Multiple Resource Inventory and Monitoring of Tropical Forest, 21-24 November 1994. Serembam, Malaysia.

Woodward, C.L. 1996. Soil compaction and topsoil removal effects on soil properties and seedling growth in Amazonian Ecuador. Forest Ecology and Management 82: 197-209.

Young, A. 1989. Agroforestry for Soil Conservation. CAB International and International Council for Research in Agroforestry. CAB International, UK. 


\title{
THE EFFECT OF SKIDTRIAL CURVES ON SOIL LOSS IN A SELECTIVELY HARVESTED DIPTEROCARP FOREST IN EAST KALIMANTAN, INDONESIA
}

\section{Lopachoke Thawornwong}

\author{
Department of Forest Engineering, Faculty of Forestry, Kasetsart University, Bangkok, Thailand
}

\begin{abstract}
LOPACHOKE THAWORNWONG, 1996. The effect of skidtrail curves on soil loss in a selectively harvested dipterocarp forest in East Kalimantan, Indonesia. Soil loss from skidtrails in relation to the deflection angle of curves was investigated. Regression analysis revealed that soil loss increases with increasing deflection angle (degree of curvature). This effect was more pronounced on skidtrails on slopes < $20 \%$. On the steeper slopes more than one factor is likely to influence this relation (e.g., width and length).
\end{abstract}

Keyword: Skidtrail - cross section of skidtrail - deflection angle of curve - percent slope - skidtrail width

\section{Introduction}

Timber harvesting occurs at a large scale throughout Southeast Asia. In East Kalimantan (Indonesia), selective logging is the typical mode of forest exploitation (Nussbaum et al. 1995). Heavy machinery such as crawler tractors are used for log yarding in this area. These heavy machines alter soil physical and chemical properties. Woodward (1996) stated that both soil compaction and topsoil removal cause a decrease in macroporosity of soil and reduced water infiltration rates. These effects are particularly acute on skidtrails.

To reduce soil loss on skidtrails, trail grade must be as low as possible; maximum grades of 10-20\% are recommended (Dykstra and Heinrich 1996). Skidtrail locations should be carefully planned. Skidtrail curves are also important to consider, because on curves, vehicles reduce their speed which means that they spend relatively more time on curves than on straight portions of skidtrails. With heavy machinery, the more time they spend on a trail the more soil is likely to be compacted and subsequently lost.

The objective of this study was to investigate the effect of skid trial curves on soil loss. I determined the relationship between soil loss and the deflection angle of curves (degree of curvature) and also considered other factors such as slope and skidtrail width.

\section{Study area}

The study was conducted in the International Timber Corporation Indonesia (ITCI) concession area in East Kalimantan $\left(1^{\circ} 16^{\prime} \mathrm{S}, 116^{\circ} 18^{\prime} \mathrm{E}\right)$. The elevation of the area ranges between 230 and $300 \mathrm{~m}$ with annual precipitation of $2000-2500 \mathrm{~mm}$. The area was harvested in 1975-1976 by Weyerhauser Corporation using crawler tractors. 


\section{Methods}

Soil loss was estimated by measuring cross sections of skidtrails beneath a taut line stretched across the trail. Twenty-four cross section samples were taken at random points along a $300 \mathrm{~m}$ skidtrail. Deflection angles at each point were measured. Regression analysis was used to determine the relation between the cross-sectional area of soil loss and deflection angle.

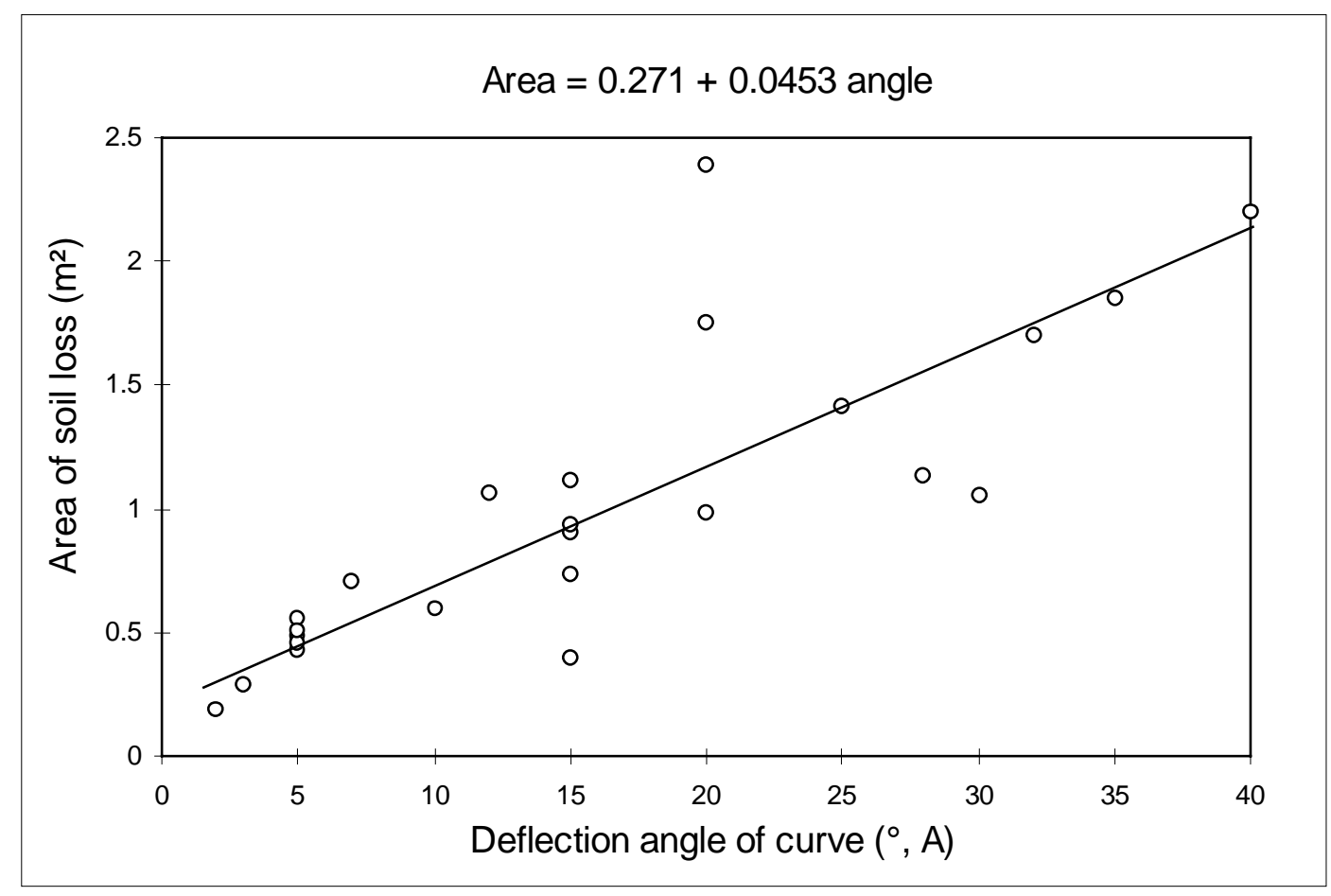

$$
A=0.3618, R^{2}=66 \%, t=6.59, P<0.05
$$

Figure 1. Soil loss $\left(\mathrm{m}^{2}\right)$ as a function of deflection angle of skidtrails.

\section{Results}

Soil loss increased with increasing deflection angle (Figure 1). The regression was significant at the $95 \%$ confidence level but the relationship between the two factors was quite variable $\left(\mathrm{R}^{2}=66 \%\right)$. However, when I included more factors that might influence soil loss (e.g., slope and skidtrail width) the coefficients of the additional terms were not significantly different from zero at the $95 \%$ confidence level. To further elucidate sources of variance I split the data into two categories; one for slopes < $20 \%$ and the other for steeper slopes. On slopes $<20 \%$, deflection angles had a very strong influence on soil loss $\left(\mathrm{R}^{2}=87 \%\right)$. On slopes $>20 \%$ deflection angles do not seem influence of soil loss as strongly. The multiple regression of soil loss as a func- 
tion of deflection angle, slope and skidtrail width revealed only the following significant relationship:

Area of soil loss $=-3.46+0.0115$ (Deflection angle $)+1.09$ (Skidtrail width $) \quad(P<0.05)$

\section{Conclusion}

Results of this study demonstrate that soil loss increases with increasing deflection angles on slopes $<20 \%$. On steeper slopes both the deflection angle and skidtrail width influence the amount of soil loss. These results suggest that when laying out skidtrails in logging areas, deflection angles of curves should be minimized; skidtrails should be as straight as possible. On steeper slopes, deflection angles and skidtrail widths should be considered. Skidtrail width depends on machine width as well as on the care with which the machines are operated. Using smaller extraction machines with trained and supervised operators is therefore critical.

\section{Acknowledgments}

The author would like to thank CIFOR, FAO, USAID, and the USDA Forest Service for accepting his application to participate in the course on Reduced Impact Timber Harvesting and Natural Forest Management. Special thanks to Francis E. Putz, Dennis P. Dykstra, Andrew Gillison, Plinio Sist, Elias, Rudolf Heinrich and Leonard A. Newell who motivated me to conduct this research. Also thanks to PT. ITCI for their hospitality and assistance in data collection in the field.

\section{References}

Dykstra, D.P. and Heinrich, R. 1996. FAO Model Code of Forest Harvesting Practice. Food and Agriculture Organization of the United Nations, Rome. 85 p.

Nussbaum, R., Anderson, J. and Spencer, T. 1995. Effects of selective logging on soil characteristics and growth of planted dipterocarp seedlings in Sabah. In: R.B. Primack and T.E. Lovejoy, Eds. Ecology, Conservation and Management of Southeast Asia Rainforests. Yale University Press, New Haven, Connecticut, USA.

Woodward, C.L. 1996. Soil compaction and topsoil removal effects on soil properties and seedling growth in Amazonian Ecuador. Forest Ecology and Management 82:197-209. 


\title{
INFLUENCE OF SLOPE AND DISTANCE FROM RIDGETOPS ON SOIL EROSION FROM SKIDTRAILS 20 YEARS AFTER LOGGING IN EAST KALIMANTAN, INDONESIA
}

\author{
Mai Van Thanh
}

Forest Science Institute of Vietnam, Chem Tuliem, Hanoi, Vietnam

\section{Introduction}

Tropical forests occupy a large area in the tropical zone of the world and are known as our planet's lungs. In many areas currently exploited for timber in the tropics, slopes are steep and logs are heavy. To overcome these problems, heavy and powerful bulldozers are used but these machines have bad effects on forest as well as on other ecosystems. Bulldozers compact the soil and scrape away the topsoil decreasing its organic matter, nitrogen and phosphorus content and water availability.

The objectives of this study were to investigate the influence of slope and distance from ridgetops on soil erosion from skidtrails 20 years after logging in East Kalimantan, Indonesia.

\section{Study area}

The study was conducted in the International Timber Corporation Indonesia (ITCI) concession area in East Kalimantan, Indonesia $\left(1^{\circ} 16^{\prime} \mathrm{S}, 116^{\circ} 18^{\prime} \mathrm{E}\right)$. The area was logged in 1976 by Weyerhauser Corporation. The elevation of the study area ranges between 230 and $300 \mathrm{~m}$ with a mean annual precipitation of 2000 to $2500 \mathrm{~mm}$.

\section{Methods}

Soil loss was measured along 24 cross sections of skidtrails on slopes ranging from $9 \%$ to $35 \%$. I also recorded skidtrail width and distance from the top of the ridge because the amount of soil erosion may depend not only on slope but also on distance from the water's starting point. I analyzed the two factors separately with simple linear regression.

\section{Results and discussion}

Results are presented in Table 1.

The relation between erosion and slope was as follows:

$$
\text { Erosion }=11.0+0.614(\text { Slope }, \%) \quad(\mathrm{P}<0.05)
$$


Table 1. Summary of data.

\begin{tabular}{|c|c|c|c|}
\hline Slope (\%) & Distance $(\mathbf{m})$ & Slope $^{*}$ Distance & Erosion $\mathbf{( c m )}$ \\
\hline 12 & 42.50 & 510.00 & 20.00 \\
\hline 10 & 92.50 & 925.00 & 18.17 \\
\hline 9 & 122.50 & 1102.50 & 13.46 \\
\hline 31 & 156.75 & 4859.25 & 40.68 \\
\hline 17 & 173.05 & 2941.85 & 26.97 \\
\hline 32 & 198.05 & 6337.60 & 41.69 \\
\hline 35 & 214.05 & 7491.74 & 20.02 \\
\hline 24 & 252.30 & 6055.20 & 11.80 \\
\hline
\end{tabular}

The relation between erosion and the product of slope and distance is described by the following regression equation:

$$
\text { Erosion }=18.7+0.00143\left(\text { Slope }{ }^{*} \text { Distance }\right) \quad(P<0.01)
$$

Clearly the amount of soil erosion depends on the slope; increasing slope is associated with increasing soil loss. But soil loss also depends on the distance from the ridgetop to the skidtrail because the more this distance increases the more rainwater accumulates so that soil loss increases too.

\section{Recommendations}

1. Skidtrails should be kept as short as possible. If this is not possible it is recommended to have sections with low slope or drains between steep sections to decrease volumes of water and rates of flow.

2. On curves the surface of the skidtrail should slope outwards so that water flows off the skidtrail thereby decreasing the amount of water flowing onto the following sections.

3. Smaller and lighter machines should be used to yard logs so as to decrease damage to the soil.

4. Low tire pressure tractors should be used instead of crawler tractors to reduce damage to the soil.

\section{Acknowledgements}

Many thanks to Francis E. Putz, Dennis P. Dykstra, Andrew Gillison, Plinio Sist of CIFOR, Elias of Bogor Agricultural University, Rudolf Heinrich of FAO, Leonard A. Newell of the US Department of Agriculture Institute of Pacific Islands Forestry for teaching this course, CIFOR, FAO, USAID, and the USDA Forest Service for financial support, and the many other people in CIFOR who contributed to this study. 


\title{
NATURAL REGENERATION ON SKIDTRAILS 20 YEARS AFTER LOGGING IN EAST KALIMANTAN, INDONESIA
}

\author{
Charles Dei-Amoah \\ Planning Branch, Forestry Department, Kumasi, Ghana
}

\begin{abstract}
DEI-AMOAH, C., 1996. Natural regeneration on skidtrails 20 years after logging in East Kalimantan, Indonesia. Selective logging is the commonest form of timber harvesting in Indonesia. According to the national forest management guidelines an average of 8 trees/ha are to be felled at 35 year intervals. Ground skidding by crawler tractors (bulldozers) is the commonest system of yarding logs from the stump to the roadside. Although this yarding system alters soil physical and chemical properties that affect plant growth, it is the most favoured because of the nature of the terrain and the size of logs. To evaluate patterns of vegetation recovery after logging, the track portion and centre portion of a $300 \mathrm{~m}$ long skidtrail were compared 20 years after harvesting with crawler tractors. My study revealed no difference in the density of natural regeneration between the tracks and centre of the skidtrail. The implications of this finding for future forest management are briefly discussed.
\end{abstract}

Key words: Natural regeneration - skidding - logging damage - extraction-system skidtrail - yarding

\section{Introduction}

Selective logging is the commonest form of timber harvesting in Indonesia. During logging several extraction systems may be used including ground skidding and cable yarding systems. The most common system used is ground skidding which is associated with substantial damage to forest ecosystems (Dykstra and Heinrich 1996).

An average of $1643 \mathrm{~m}^{2}$ / ha of the forest floor is exposed due to skidding while logging at an average intensity of 8 trees/ha in East Kalimantan (Elias 1996). Adam et al. (1993 in Dei-Amoah 1993) reported an average skid track intensity of $5.1 \%$ and $5.5 \%$ in Ghana after skidding an average of only 3 trees $/$ ha.

Ground-based yarding of timber alters soil physical and chemical properties that affect plant growth (e.g., Woodward 1996). Loss of organic matter when topsoil is scraped away by bulldozers may also negatively affect plant growth (Lal et al. 1975, Nussbaum et al. 1995 in Woodward 1996). There are also negative effects on seedling establishment and growth due to skidding which are often attributed to changes associated with soil compaction, including reduced infiltration rates and increased resistance to root penetration (Greacen et al. 1980 in Woodward 1995). Although there are various ways to improve soil conditions, Nussbaum et al. (1995) found that fertilisation following compaction with or without removal of topsoil has the most significant increase growth rates in seedlings on compacted soils in Malaysia.

The objective of my study was to determine whether there is a difference between the density of natural regeneration in tracks and centres of skidtrails 20 years after logging. 


\section{Materials and Methods}

\section{Site description}

The study was conducted in International Timber Corporation Indonesia (ITCI) concession near Balikpapan, East Kalimantan, Indonesia $\left(1^{\circ} 16^{\prime} \mathrm{S}, 116^{\circ} 18^{\prime} \mathrm{E}\right)$. The area was logged in 1996 using a crawler tractor (L. Marpaung, pers. comm., 1996). The terrain is steep with elevations ranging between 230 and $300 \mathrm{~m}$. The climate is equatorial with a mean annual rainfall of about $2500 \mathrm{~mm}$. The vegetation is dominated by pioneer trees (Maranga spp.) and residual dipterocarps (Tun 1996).

\section{Methods}

A skidtrail of about $300 \mathrm{~m}$ long was used for this study. The first sample point was selected at random and subsequent sample points were located at intervals of about $7.5 \mathrm{~m}$. At each sample point, a $2.4 \mathrm{~m}^{2}$ plot was established in either the track or center of the skidtrail and all seedlings $<1 \mathrm{~m}$ tall were counted.

\section{Data analysis}

The results were analysed using a Student's t-test on the logarithmic transformation of the number of seedlings per plot.

\section{Results}

Seedling densities in skidtrail tracks and the centres were similar. The number of seedlings in the skidtrail tracks ranged from 3 to 40 per $2.4 \mathrm{~m}^{2}$ (mean $=13, \mathrm{SE}=2.2$, $\mathrm{N}=22$ ) while the number of seedlings in the centre portion ranged from 1 to 38 per $2.4 \mathrm{~m}^{2}($ mean $=14, \mathrm{SE}=2.3, \mathrm{~N}=22)$. This difference is not significant $(\mathrm{t}=0.2, \mathrm{df}=40$, $\mathrm{P}=0.84)$.

\section{Discussion}

In spite of the damage caused by ground skidding, in many forest areas with steep terrain, large trees, and high precipitation, crawler tractors are likely to remain the most common type of skidding machine used (Dykstra and Heinrich 1996). Hence there is a need to reduce their impacts on soil and the residual forest.

This study did not reveal any difference in the density of seedlings within skid trails. This finding may be attributed to the fact that the drivers of the skidders did not follow a particular course along the skidtrail hence severe soil damage was not restricted to the tracks.

It is imperative that forest managers refine the modes of skidding and preskidding operations to facilitate a reduction in skidding intensity. By implication this would reduce the exposure of the forest floor which has great impacts on the dynamics of the forest. Such intervention would include careful planning of skidtrail locations, directional felling, training of logging crew and the use of low ground pressure crawler tractors. 


\section{Acknowledgements}

I am grateful to CIFOR, FAO, USAID, and the USDA Forest Service for sponsoring my participation in this training seminar. I also thank all the course instructors who worked tirelessly to see the class through to its successful end. The management and staff of PT. ITCI deserve commendation for their concern while the team was in their concession. Finally, I would like to thank the Forestry Department of Ghana for allowing me to participate in this seminar.

\section{References}

Adam,A.R., Ofosu Asiedu, A., Dei-Amoah ,C. and Asante-Asiamah, A. 1993. Wood waste and damage in Asukese and Afram Headwaters forest reserves, Ghana. A subproject under ITTO PROJECT PD74/90, Better utilisation of tropical timber resources in order to improve sustainability and reduce negative ecological impacts. Forestry Research Institute of Ghana. 85 p.

Dei-Amoah, C. 1993. Assessment of damage to residual stock in felling gaps in the tropical high forest of Ghana. Case study: Asukese and Afram Headwaters forest reserves. M.Sc. thesis. University of Aberdeen, United Kingdom.

Dykstra, D.P. and Heinrich R., 1996. FAO Model Code of Forest Harvesting Practice. Food and Agriculture Organization of the United Nations, Rome. 85 p.

Elias. 1996. Stand damage and regeneration in forest concession areas of PT. Kiani Lestari and PT. Narkata Rimba, East Kalimantan, Indonesia. In: Research Methods for Reduced-Impact Logging: Workshop Results. CIFOR, Bogor, Indonesia. 27 p.

Greacen, E.L. and Sands, R. 1980. Compaction of forest soils. A review. Australian Journal. of Soil Resources 18: 16-189.

Lal, R., Kang B.T., Moorman, F.R., Juo, A.S.R. and Mooman, J.C. 1975. Soil management problems and possible solutions in western Nigeria. In: E. Bornemisa and Alvarado (Eds.) Soil Management in Tropical America, North Carolina State University Press, Raleigh, NC, 372-408.

Nussbaum, R., Anderson, J. and Spencer, T. Factors limiting the growth of dipterocarps and pioneer tree seedlings planted on disturbed soils following rainforest logging in Sabah, Malaysia. Forest Ecology and Management. (in press).

Tun, T. 1996 Basal areas of pioneer and primary tree species 20 years after logging in East Kalimantan, Indonesia. In: Research Methods for Reduced-Impact Logging: Workshop Results. F.E. Putz, Elias, P. Sist, D. Dykstra, and R. Heinrich, editors. CIFOR Special Publications.

Woodward, C.L. 1996. Soil compaction and topsoil removal effects on soil properties and seedling growth in Amazonian Ecuador. Forest Ecology and Management 82:197-209. 


\title{
TREE DAMAGE TWENTY YEARS AFTER LOGGING IN EAST KALIMANTAN, INDONESIA
}

\section{Dar-Hsiung Wang}

Taiwan Forestry Research Institute, Division of Forest Management, Taipei, Taiwan

\begin{abstract}
WANG, D. H., 1996. Tree damage twenty years after logging in East Kalimantan, Indonesia. Tree damage is an issue attracting growing attention from tropical forest managers. Damage to trees in selectively logged forests may vary with distance from skidtrails. In this case study in a forest in East Kalimantan, however, there was no difference in damage to trees with varying distance from a main skidtrail 20 years after logging.
\end{abstract}

Key words: Tree damage - tropical forest - logging operations

\section{Introduction}

Tropical forests are one of the most valuable natural resources in the world. Unfortunately, during recent decades tropical forests have been disappearing at the rate of tens of thousands $\mathrm{km}^{2}$ per year (Johnson and Cabarle 1993). Besides removal of trees by selective cutting, the residual stands have also suffered from increased likelihood of damage caused by other factors (e.g., insects and fire). Logging operations alter stand structure and in turn modify the approach of management appropriate for subsequent yield cycles (Dykstra and Heinrich 1996). The impact of logging on tropical forest, therefore, has attracted growing attention from silviculturists and forest managers. For residual trees, the impact of logging may vary as a function of distance from the main skidtrail. This impact effect may change over time after logging as well. A case study on tree damage assessment 20 years after logging in East Kalimantan was carried out to evaluate the impact of logging over time.

\section{Materials and Methods}

\section{Site description}

The site of this study was located in the ITCI Concession in East Kalimantan, Indonesia with an elevation of $230-300 \mathrm{~m}$ and precipitation of $2000-2500 \mathrm{~mm} /$ year. The study area was logged in 1976 using crawler tractors. Logging intensity was estimated as $90-120 \mathrm{~m}^{3} / \mathrm{ha}$.

\section{Methods}

Two distances $(0-5 \mathrm{~m}$ and $15-20 \mathrm{~m})$ from the main skidtrail were used in the assessment of tree damage. Twelve points were randomly located at each distance, and the 
status of the nearest ten trees $>20 \mathrm{~cm}$ dbh were assessed at each point. Trees with bark or bole damage were regarded as defective. A Mann-Whitney $U$ test was used to compare the proportion of damaged trees at each distance.

\section{Results and Discussion}

There was no statistically significant difference in the proportion of trees damaged at distance $0-5 \mathrm{~m}$ (median $=7 \%$ ) and $10-15 \mathrm{~m}$ (median $=6.5 \%$ ) from the main skidtrail ( $\mathrm{U}=150, \mathrm{P}>0.05)$. This result may be explained by the following: (1) in this area in addition to the main skidtrail there are many secondary skidtrails that may have caused added damage to trees in the 10-15 m group, and (2) the impacts of logging on timber quality perhaps decreased over time such that 20 years later, no difference caused by distance from the skidtrail could be detected.

\section{Conclusion}

Residual forest damage is an issue of great concern to tropical forest managers. While forest damage can be attributed to several factors, uncontrolled logging operations in selectively logged forests are particularly destructive (e.g. Pinard et al. 1995). In this study, it was shown that 20 years after logging, there was no difference in damage of trees with varying distance from the main skidtrail.

\section{Acknowledgments}

The author is grateful to Dr. Dennis Dykstra, Professor Francis Putz, Dr. R. Heinrich, Dr. Elias, Dr. P. Sist and the staff of Center for International Forestry Research for their guidance and assistance with this study. A sincere thanks is given to PT. ITCI as well.

\section{References}

Dykstra, D.P. and R. Heinrich. 1996. FAO Model Code of Forest Harvesting Practice. Food and Agriculture Organization of the United Nations, Rome. 85 p.

Johnson, N., and Cabarle, B. 1993. Surviving the Cut: Natural Forest Management in the Humid Tropics. World Resources Institute. $71 \mathrm{p}$.

Pinard, M. A., Putz, F. E., Tay, J., and Sullivan, T. 1995. Development and implementation of harvesting guidelines-the Reduced-Impact Logging Project in Sabah, Malaysia. J. For. 93:41-45. 


\title{
BASAL AREAS OF PIONEER AND PRIMARY TREES 20 YEARS AFTER LOGGING IN EAST KALIMANTAN, INDONESIA
}

\section{Tin Tun}

Institute of Forestry, Yezin, Myanmar

\begin{abstract}
TUN, T., 1996. Basal areas of pioneer and primary trees 20 years after logging in East Kalimantan, Indonesia. Twelve circular sample plots of $201 \mathrm{~m}^{2}$ each were randomly located in the logged-over forest. Diameter of trees at breast height were measured in all the plots, and basal areas were determined. There was no statistically significant difference in basal area between pioneer species $\left(19.15 \mathrm{~m}^{2} / \mathrm{ha}\right)$ and primary tree species $\left(17.75 \mathrm{~m}^{2} / \mathrm{ha}\right)$.
\end{abstract}

Key Words: basal area - pioneer and primary species - conventional and reducedimpact logging

\section{Introduction}

Indonesia has about 144 million ha of tropical rain forests with 94 million in production forests (Elias 1996). Indonesia's forests are harvested according to specific rules defined in the Indonesian Selective Cutting and Planting System known as TPTI (Tebang Pilih Tanam Indonesia). Forests differ in the regeneration requirements of their most valuable species and in their response to different silvicultural treatments (e.g., Putz 1992). Logging damage occurs, no matter how well planned and carefully implemented the operations.

Damage to residual stands by logging in Indonesia has been clearly documented by Elias (1996) and Sist (1996). Damage mainly occurs by the uncontrolled felling of trees, and the use of bulldozers to skid logs on unplanned skidtrails. Consequently, canopy gaps are opened due to felling of trees, skidtrail and road construction in the forests. These canopy openings result in altered tree species composition. Pioneer species of low commercial value grow rapidly in these gaps; as a result the proportion of the dipterocarp may be reduced.

Sist (1996) reported that crown, stem, and uprooting damage from conventional logging was $48 \%$ whereas the damage was $30.5 \%$ in reduced-impact logging. Much of the reduction in logging damage in well managed forests is the result of careful harvest planning (Dykstra and Heinrich 1996). The objective of this study was to find out if there is any difference in basal areas between pioneer and primary tree species.

\section{Study Area}

The study area was in East Kalimantan, Indonesia $\left(1^{\circ} 16^{\prime} \mathrm{S}, 116^{\circ} 8^{\prime} \mathrm{E}\right)$ at an elevation of 230 to $300 \mathrm{~m}$. The site is very hilly with steep slopes. The climate is equatorial with a 
mean annual rainfall of about $2500 \mathrm{~mm}$. The bedrock is primarily alluvial deposits (mudstone, siltstone, sandstone), and the soils are mainly Ultisols with some Entisols (Sist 1996). Prior to logging the vegetation was dominated by Dipterocarpaceae. Pioneer trees such as Tristania spp., Macaranga spp. and Anthocephallus spp. are abundant in logged-over areas.

\section{Method}

Twelve circular sample plots of $201 \mathrm{~m}^{2}$ each were randomly located in the forest. Diameter at breast height ( $\mathrm{dbh}$ ) was measured for both pioneer and primary trees in these plots and their respective basal areas determined. The total basal areas of pioneer and primary forest trees were compared using a t-test.

\section{Results}

The mean basal area for pioneer and primary trees were $0.38 \mathrm{~m}^{2}$ and $0.35 \mathrm{~m}^{2}$ per sample plot, respectively $\left(19.15 \mathrm{~m}^{2} /\right.$ ha and $17.75 \mathrm{~m}^{2} / \mathrm{ha}$, respectively. This difference is not significant $\left(\mathrm{SD}_{\text {Pioneer }}=0.18, \mathrm{SD}_{\text {Primary }}=0.23, \mathrm{t}=0.34, \mathrm{P}=0.74, \mathrm{DF}=20\right.$ ).

\section{Discussion}

Tree species composition in tropical rain forests is very dynamic, and among the many species only a few tree species are commercial. Stand densities are also very high making it difficult to carry out logging. Opening of the canopy during logging has to be controlled in order to minimize the invasion of undesirable pioneer trees. Uncontrolled logging causes much damage to the residual stand and creates large openings in the forest (Dykstra and Heinrich 1996). An example of this was observed after conventional logging carried out in the International Timber Corporation Indonesia area 20 years ago. The proportion of basal area of pioneer trees is over half of the total basal area of the forest. The large proportion of pioneer trees in this forest can be attributed to uncontrolled conventional logging. In this situation the volume of valuable primary trees is reduced by invasion of pioneers. Large gaps were formed from the damage to trees usually from uncontrolled direction of felling and the lack of pre-planned skidtrails.

\section{Conclusion}

Large gaps caused by conventional logging methods favor rapid colonization of pioneer trees in tropical rain forests in East Kalimantan. Conventional logging results in heavy damage to forest stands, and primary forest trees are often unable to recover from injuries. Thus, reduced-impact logging is recommended so that development of pioneer trees can be kept to a minimum, and so that primary tree species can be maintained to a maximum extent. 


\section{Acknowledgements}

The author is very grateful to Professor Francis E. Putz, Dr. R Heinrich (FAO), Dr. D. Dykstra, Dr. P. Sist Scientist, Dr. Elias, and all the staff of the Center for International Forestry Research for their kind guidance and assistance in carrying out this project. The author also thanks the International Timber Corporation Indonesia (ITCI) for their hospitality.

\section{References}

Dykstra, D.P. and R. Heinrich. 1996. FAO Model Code of Forest Harvesting Practice. Food and Agriculture Organization of the United Nations, Rome. 85 p.

Elias 1996. Field research techniques and permanent plot establishment in tropical natural forest. International Training Seminar on Reduced-Impact Timber Harvesting and Natural Forest Management, July 15-27, 1996, Indonesia.

Putz, F. E 1992. Rainforests are our business. Conference held in Sydney, Australia.

Sist, P. 1996. Reduced-impact logging trials in East Kalimantan (STREK Project): harvesting volumes and damage assessment. CIFOR/FAO/USAID/USDA-FS International Research Training Seminar on Reduced-Impact Timber Harvesting and Natural Forest Management, July 15-27, 1996, Indonesia. 


\section{SLOPE INFLUENCE ON TREE DENSITY 20 YEARS AFTER LOGGING IN EAST KALIMANTAN, INDONESIA}

\section{Lorentz Marpaung}

PT. International Timber Corporation Indonesia, Balikpapan, Indonesia

MARPAUNG, L., 1996. Slope influence on tree density 20 years after logging in East Kalimantan, Indonesia. Forest harvesting causes openings in the canopy and as a result more light reaches the forest floor. This light stimulates tree regeneration and growth. Slopes influence the amount of sunlight reaching the trees. This study found higher tree densities on slopes than on level areas.

Key words: Gaps opening - density - growth - slope - sunlight penetration

\section{Introduction}

Harvesting creates openings in the forest which allow sunlight to penetrate onto the forest floor that stimulates tree growth and increases tree density. Since sunlight is one of the resources needed for photosynthesis, an increase in this resource stimulates growth (Richards 1952). The amount of light that penetrates into the forest largely depends on canopy gap size and slope aspect.

\section{Study Area}

The study was conducted in East Kalimantan $\left(1^{\circ} 16^{\prime} \mathrm{S}, 116^{\circ} 18^{\prime} \mathrm{E}\right)$ at an elevation of approximately $230-300 \mathrm{~m}$. In this area the mean annual precipitation is $2000-2500$ $\mathrm{mm}$. The area was logged in 1976, 20 years prior to this study.

\section{Methods}

The plots were randomly located accordingly to slope classes of $0-10,11-20,21-30$, $31-40$, and $41-50 \%$. As many as three circular plots of $10 \mathrm{~m}$ radius were established randomly in each slope class and all trees $>20 \mathrm{~cm}$ DBH within the plots were measured and recorded.

\section{Results and Conclusion}

The relationship between slope $(\%)$ and density was significant $\left(t=8.0, P<0.05, R^{2}=\right.$ $83.2 \%)$. The fitted regression equation is:

$$
\text { Number of trees }=2.00+0.147 \text { (Slope) }
$$

This relationship may be due to an increasing amount of sunlight reaching the crowns of trees with an increase in slope. 


\section{Acknowledgments}

I would like to thank CIFOR, FAO and USAID for sponsoring my participation in the 1996 training course. I would also like to thank all off the instructors and staff their help during my training. Lastly, I wish to thank PT. ITCI for their hospitality during the field study.

\section{References}

Putz, F.E., Elias, P. Sist, D. Dykstra and R. Heinrich, Editors. 1996. Research Methods for Reduced-Impact Logging: Workshop Results. CIFOR Special Publication.

Richards, P. W. 1952. The Tropical Rain Forest, An Ecological Study. Cambridge Univ. Press, London. 


\title{
DIPTEROCARP SEEDLING DENSITIES ADJACENT TO A SKIDTRAIL AND IN RESIDUAL FOREST 20 YEARS AFTER LOGGING IN EAST KALIMANTAN, INDONESIA
}

\author{
A. Suyana
}

Forestry Research Institute, Samarinda, Indonesia

SUYANA, A., 1996. Dipterocarp seedling densities adjacent to a skidtrail and in residual forest 20 years after logging in East Kalimantan, Indonesia. Natural regeneration is the key to successful timber harvesting management systems in tropical forest. In this study, 15 plots $(2 \times 2 \mathrm{~m})$ located randomly adjacent to skidtrails and in residual forest were used to measure seedlings densities. The density of dipterocarp seedlings adjacent to skidtrails was significantly greater $(11,175$ seedlings/ha) than in the residual forest (3,650 seedlings/ha).

Keywords: Dipterocarp - seedling density - skidtrail - residual trees - Kalimantan

\section{Introduction}

Natural dipterocarp forests, particularly those in Kalimantan and Sumatra, comprise one of the most valuable economic forest resources in Indonesia. They have been utilized for wood production for more than a quarter century, and earn the country large amounts of foreign exchange. Most of the resulting logged-over areas (residual forest stands) have not been managed well for various reasons. One of the reasons is the unavailability of appropriate technology for improvement of the heterogeneous logged-over area. Natural regeneration is the key to successful selective management of the forest, and sufficient seedlings or advanced growth (residual stocking) must survive logging to form the next timber crop. To better understand how dipterocarp seedlings respond to proximity to skidtrails, I studied the densities of dipterocarp seedlings adjacent to a skidtrail and in the residual forest.

\section{Study area}

The study area in the PT. ITCI Concession in East Kalimantan $\left(1^{\circ} 16^{\prime} \mathrm{S}, 116^{\circ} 18^{\prime} \mathrm{E}\right.$; elevation $230-300 \mathrm{~m}$ ) supports dipterocarp forest 20 years after logging. The climate is type A with rainfall of about $2000-2500 \mathrm{~mm} / \mathrm{yr}$. The terrain consist of series of flat and steep ridges varying from $5-35 \%$ slope.

\section{Methods}

Densities of dipterocarp seedlings $<2 \mathrm{~m}$ tall were compared adjacent to and far from skidtrails. Fifteen sample plots $2 \times 2 \mathrm{~m}$ were randomly located $1 \mathrm{~m}$ from skidtrails, and fifteen sample plots were located $20-50 \mathrm{~m}$ into the residual forest. I compared the two treatment means with a t-test. 


\section{Results and discussion}

Openings in the forest canopy created by logging are particularly common along logging-roads and skidtrails. In the research area, these gaps are extremely wide and are dominated by pioneer species such as Macaranga spp. and some dipterocarp species. The density of dipterocarp seedlings adjacent to skidtrails (mean $=4.47 / 4 \mathrm{~m}^{2}$, $\mathrm{SD}=2.5, \mathrm{~N}=15$ ) was higher than in the residual forest area (mean $=1.47 / 4 \mathrm{~m}^{2}, \mathrm{SD}=$ $1.30, \mathrm{~N}=15 ; \mathrm{t}=4.12, \mathrm{P}<0.05)$. This difference may be due to most dipterocarp species being light-demanding and growing well under gap conditions. Hartshorn (1978) stated that transient canopy openings, or gaps as they are popularly known, stimulate natural regeneration of many shade tolerant plant species, some of which are valuable timber trees. For a forest in Central America he estimated that $50 \%$ of the tree species are dependent on gaps for successful regeneration.

\section{Conclusion}

Dipterocarp seedling density adjacent to skidtrails was greater than in the residual forest. Average numbers of seedlings were 11,175 seedlings/ha adjacent to the skidtrail and 3,650 seedlings/ha in the residual forest. Canopy opening created by logging can stimulate dipterocarp seedlings growth but also stimulates weed growth. Further research should be conducted on the mortality of dipterocarp seedlings in gaps, and on optimum gaps sizes for stimulating dipterocarp regeneration.

\section{Acknowledgments}

I would like to thank CIFOR for allowing me to participate in the training seminar on reduced impact logging. I also wish to thank all instructors of the training seminar especially Dr. Francis E. Putz who spent much time improving this paper, and Dr. Elias who provided support and some technical suggestions.

\section{References}

Elias. 1996. Stand Damage and Regeneration in Forest Concession Areas of PT. Kiani Lestari and Narkata Rimba, East Kalimantan. Indonesia. CIFOR Training Series.

Hartshorn, G.S. 1989. Gap-phase dynamics and tropical tree species richness in tropical forest. In: Tropical Forests. Academic Press, Orlando, Florida.

Pinard, M.A. and F.E. Putz. 1996. Retaining forest biomass by reducing logging damage. Biotropica 28. 


\title{
RELATION BETWEEN TREE DENSITY AND MAXIMUM DIAMETER OF MACARANGA TREES IN DIFFERENT SIZE GAPS 20 YEARS AFTER LOGGING IN EAST KALIMANTAN, INDONESIA
}

\author{
Rudy A. Guzmán Gutíerrez
}

Proyecto BOLFOR, Santa Cruz, Bolivia

\begin{abstract}
GUZMÁN GUTÍERREZ, R., 1996. Relation between tree density and maximum diameter of Macaranga trees in different sized gaps 20 years after logging in East Kalimantan, Indonesia. Forest harvesting creates openings in the canopy that initiate succession; pioneer species rapidly colonize disturbed areas. The tropical forests of East Kalimantan are selectively harvested, opening the canopy, and beginning the process of succession. There is a positive relationship between the maximum diameter of Macaranga spp. trees and the number of conspecific individuals that grow in forest gaps. The results show that the gaps with the most Macaranga trees also have the Macaranga with the largest diameter.
\end{abstract}

Key Words: Macaranga spp. - pioneer species - gaps - skidtrails - harvesting

\section{Introduction}

Succession occurs after forest is disturbed and leads to changes in the composition and structure of the forest. Canopy openings in the forest can occur by natural events (e.g., winds, storms, fires) or due to anthropogenic forces (e.g., wood harvesting, shifting cultivation; Hartshorn 1990). These events alter the conditions in primary forest and promote the revegetation of gaps by pioneer species. These pioneer species (e.g., Ochroma spp. and Cecropia spp. in the neotropics and Antocephalus spp. and Macaranga spp. in the Asian tropics) grow rapidly, have high light requirements, short life cycles, and initiate the process of secondary succession. In addition pioneer species are aggressive competitors, produce large volumes of low density wood, and compete inter- and intra- specifically in large gaps (Whitmore 1990). After the pioneer species have colonized logged-over forest, the initial gaps can be approximately delineated as the areas with clusters of these trees.

This study considers the relationship between the number of Macaranga spp. trees that in gaps and the diameter of the largest of these trees. The hypothesis is that in areas with many Macaranga trees, the diameter of the largest tree in the cluster will be higher than in areas with a fewer Macaranga trees. 


\title{
Materials and Methods
}

\author{
Site description
}

This study was carried out in the International Timber Corporation Indonesia-ITCI concession, in East Kalimantan, Indonesia ( $\left.1^{\circ} 16^{\prime} \mathrm{S}, 118^{\circ} 18^{\prime} \mathrm{E}\right)$. The site is $230-300 \mathrm{~m}$ above sea level and the annual rainfall is $2000-2500 \mathrm{~mm}$. The primary forest is a lowland tropical rainforest with a predominace of Dipterocarpaceae and a smaller proportion of Sapotaceae, Myrtaceae, and Lauraceae. The study area was logged in 1976; in 1996 the canopy was again closed but about half of the total forest basal area was composed of Macaranga trees (Euphorbiaceae). The canopy height was $10-30 \mathrm{~m}$ and the understorey was open with some palms.

Former canopy gaps now occupied by clusters of Macaranga trees were located at random in the forest $(\mathrm{N}=14)$. In each gap, all Macaranga trees $>10 \mathrm{~cm}$ dbh were counted and the tree with the largest dbh was measured.

\section{Results}

Regression analysis revealed a significant positive relationship between number of Macaranga trees per cluster and the diameter of the largest tree. In other words, as the number of trees increased, the $\mathrm{dbh}$ of the largest tree in that cluster also increased. The regression equation is the following:

Maximum $\mathrm{dbh}=39.3+1.07$ (number of Macaranga trees/gap) $\quad\left(\mathrm{P}<0.01, \mathrm{R}^{2}=41 \%\right)$

\section{Discussion}

The areas colonized by Macaranga spp. apparently resulted from the logging that occurred 20 years prior to this study. Whitmore (1990) also noted that pioneer species germinate in gaps and grow quickly where light is plentiful. The largest clusters of Macaranga spp. were found in the largest gaps, presumably where the greatest disturbance occurred in 1976. In large gaps with a high density of pioneer trees, the trees compete with each other, with some individuals growing more rapidly and reaching the canopy first. Once the successful individuals reach the canopy, they have access to all of the light they need and can continue to grow rapidly in diameter.

In smaller gaps the surrounding forest can close the opening of the canopy faster than in the larger gaps. Therefore, in these smaller gaps, there is less opportunity for the pioneer species to colonize and grow to reach the canopy before closure. It is because of this that in the smaller clusters of Macaranga spp. the largest tree was small in diameter in comparison with trees in the larger gaps.

Because of the lack of directional felling and the lack of pre-planned skidtrails conventional harvesting tends to cause large openings in the canopy. This type of harvesting, as opposed to reduced-impact harvesting, creates more damage that in turn changes the composition of the residual forest. With the introduction of many pioneer species, regeneration of commercial trees (e.g., dipterocarp species) is sup- 
pressed. In conclusion, canopy opening during logging should be minimized to promote recolonization by dipterocarps rather than pioneer trees species.

\section{Acknowledgements}

I wish to thank CIFOR and FAO for supporting my participation in the 1996 training seminar on reduced-impact logging and research methods. Special thanks to Dennis Dykstra, Francis E. Putz, Elias, Plinio Sist, Rudolf Heinrich, and the staff at CIFOR for their technical advice and assistance during the course and my field work. I also wish to thank ITCI for their hospitality during our trip to East Kalimantan and Lisa Zweede for her generous assistance with an earlier version of this manuscript.

\section{References}

Hartshorn, G.S. 1989. Gap-phase dynamics and tropical tree species richness. In: Tropical Forests, edited by L.B. Holm-Nielsen, I.C. Nielsen, and H. Balslev. Academic Press, Orlando, Florida.

Whitmore, T.C. 1990. An Introduction to Tropical Rain Forest. Oxford University Press, New York. 


\title{
EFFECT OF NEAREST NEIGHBOR TREE SPECIES ON MACARANGA DIAMETER IN A LOGGED FOREST IN INDONESIA
}

\section{Priscila Dolom}

Forestry Development Center, University of the Philippines at Los Baños, College of Forestry, Laguna, Philippines

\begin{abstract}
DOLOM, P., 1996. Effect of nearest neighbor tree species on Macaranga diameter in a logged forest in Indonesia. Creation of large canopy openings can lead to extensive pioneer tree invasion. Although pioneer trees establish and grow simultaneously in gaps of the same age, they vary in their diameter growth rates. The effect of nearest neighbor tree species on the diameter of Macaranga trees was studied in a loggedover forest in East Kalimantan. The diameters of Macaranga trees were larger when they were nearest trees of other species.
\end{abstract}

Key words: Pioneer tree - logged-over forest - Macaranga spp.

\section{Introduction}

Logging has substantial effects on forest ecosystems. Disruption of forest structure through the creation of many large gaps encourages the growth of light-demanding species. Growth rates in logged-over forest have been found to be correlated with crown exposure (Korsgaard 1992, van Daalen 1993), but large canopy gaps can lead to extensive vine and pioneer tree invasions. Weedy species may be more likely to colonize conventional logging areas because of both more open canopy and more soil disturbance (Chan and Udarde 1977, Cannon et al. 1994).

Within large openings in logged-over areas, even-aged cohorts of pioneer trees develop; however, there are differences in the diameter growth rates that may be related to other factors. One of the factors that can affect diameter growth is competition. The objective of this the study was to determine the effect of neighboring trees on diameter growth of Macaranga trees.

\section{Materials and Methods}

\section{Site description}

The study area is located in the district of Pasir in East Kalimantan in an area logged 20 years before my study $\left(1^{\circ} 16^{\prime} \mathrm{S}, 116^{\circ} 18^{\prime} \mathrm{E}\right)$. The elevation is about $230-300 \mathrm{~m}$ asl. The annual rainfall ranges from 2,000-2,500 $\mathrm{mm}$ while the relative humidity averages about $85 \%$. The temperature range is $24{ }^{\circ} \mathrm{C}$ to $32{ }^{\circ} \mathrm{C}$. The study area is dominated by Shorea spp. and Macaranga spp. Enrichment planting was undertaken in the area three years after logging but apparently few of the planted seedlings survived. 
Methods

Macaranga trees $>10 \mathrm{~cm}$ dbh were selected at random in a 4 ha area. The diameter at breast height $(\mathrm{dbh})$, total height and distance to its nearest neighbor tree were measured. The nearest neighbor tree was identified and its dbh and total height were measured as well.

\section{Data analysis}

A total of 50 trees were sampled. The effect of the neighboring tree species on the diameter of Macaranga trees was determined by comparing the dbh means of Macaranga trees nearest other Macarangas and Macaranga trees nearest trees of other species.

\section{Results}

Macaranga dbh ranged from 10-65 $\mathrm{cm}$ while the distance to nearest neighbors ranged from 1-8 $\mathrm{m}$. The means of the dbh of focal trees in two treatments differed significantly (Table 1).

Table 1. Size of Macaranga trees nearest other Macaranga trees or nearest trees of other species.

\begin{tabular}{|l|c|c|c|}
\hline Nearest Species & $\mathbf{N}$ & Mean DBH & Standard Deviation \\
\hline Macaranga $(\mathrm{cm})$ & 26 & 35.9 & 13.7 \\
\hline Other species $(\mathrm{cm})$ & 24 & 43.0 & 11.7 \\
\hline
\end{tabular}

$$
\mathrm{t}=1.96, \mathrm{P}<0.05, \mathrm{df}=47
$$

\section{Discussion}

The diameter of Macaranga trees was greater when near other tree species than when nearest the same species, suggesting that the neighbouring species may influence diameter growth of Macaranga trees. This study suggests that differences in the diameter of Macaranga trees is influenced by competitive interactions with their neighbors. Though fewer in number than Macaranga, the residual trees may show an effect on the diameter growth of pioneer trees. Competing species appear to coexist by virtue of differentiation of their realized niches.

\section{Conclusion}

Twenty years after logging, the diameter of Macaranga trees was greater when near other tree species. This pattern can be attributed to the ability of Macaranga trees to 
out-compete their neighbours. Macaranga may have different a diameter growth rate when surrounded by neighbour trees of other species. Although many other factors affect the diameter growth of Macaranga trees, I conclude on the basis of this study that neighbour trees also affect their growth.

\section{Acknowledgement}

The author is grateful to CIFOR for providing support in the conduct of the study. I also thank FAO for funding my participation in this workshop, and Dr. Rudolf Heinrich for his untiring technical support. Nani Djoko and Lia Wan greatly facilitated our travel and accommodations and Dr. Francis Putz gave many comments on an earlier draft of this manuscript. ITCI Logging Company kindly allowed the author to use their area as a study site. I acknowledge the ITCI Company management for their hospitality, especially Foresters Suhardi and Jajang for providing information about the study area and for species identification, respectively. I also thank the Reduced Impact Logging Training Coordinator, Lecturers and Participants for comments and suggestions that made this study possible.

\section{References}

Begon, M. and Mortimer, M. 1986. Population Ecology: A Unified Study of Animals and Plants. Blackwell Scientific Publications. Oxford, UK.

Chan, D. N. P. and Udarbe, M. P. 1977. The effectiveness of current silvicultural practice in Sabah. Malaysian Forester 40:27-35.

Dykstra, D.P. and R. Heinrich. 1996. FAO Model Code of Forest Harvesting Practice. Food and Agriculture Organization of the United Nations, Rome. 85 p.

Escobin, R. 1996. Macaranga tree density variation in felling gaps in a logged over forest in East Kalimantan, Indonesia. In: Research Methods for Reduced Impact Logging: Workshop Results, F.E. Putz , Elias, P. Sist, D. Dykstra and R. Heinrich, editors. CIFOR Special Publication.

Korsgaard, S. 1992. An analysis of growth parameters and timber yield prediction. The Council for Development Research, Copenhagen, Denmark.

Pinard, M. and Putz, F. E. 1996. Retaining forest biomass by reducing logging damage. Biotropica 28. 


\title{
TREE SEEDLING DENSITIES UNDER PATCHES OF MACARANGA AND UNDER OTHER TREE SPECIES 20 YEARS AFTER LOGGING
}

\author{
Ahmad Budiaman \\ Faculty of Forestry, Bogor Agricultural University, Bogor, Indonesia

\begin{abstract}
AHMAD, B., 1996. Tree seedling densities under patches of Macaranga and under other tree species 20 years after logging. A research project on densities of commercial tree seedlings was carried out in a logged-over area in East Kalimantan, Indonesia. Fifteen plots were established under patches of Macaranga spp. and 15 under other tree species. Densities of commercial tree seedlings under Macaranga spp. were significantly greater than under other tree residual species. Results of this study support the need to apply further silvicultural treatments where logging damage is severe.
\end{abstract}

Key words: commercial seedlings - logged-over area - enrichment planting.

\section{Introduction}

Forest harvesting in Indonesia is based on the Indonesia Selective Cutting and Planting System (TPTI) in which all commercial timber trees $>50 \mathrm{~cm}$ dbh are harvested in permanent production forest; trees $>60 \mathrm{~cm}$ are harvested in limited production forest. In TPTI, the minimal number of nucleus trees (commercial tree species with $\mathrm{dbh} \geq 20 \mathrm{~cm}$ ) that must remain after logging is at least 25 stems per ha.

Selective logging using tractor skidding in Indonesia has been underway since the early 1970s. Concessions are given by the Indonesian Forestry Department for a 20 year period. Unfortunately, improper harvesting operations often lead to unnecessary damage to residual stands and soils. The results of the STREK Project showed that conventional (normal) logging practices have substantial and avoidable impacts on the residual stand (Bertault and Sist 1995). Uncontrolled logging results in excessive damage to the residual forests and reduces the forest's value for future timber production (Ewel et al. 1980, Pinard et al. 1995). The average magnitude of total damage to residual stands during selective logging in Southeast Asian is 35$45 \%$. The growth of dipterocarps seedlings after logging, therefore, is very important in this region, because dipterocarps are the principal timber trees (Nussbaum et al. 1995).

To maintain production of commercial trees, including dipterocarps, monitoring of commercial seedlings should be carried out by skilled foresters. Information on the abundance of natural regeneration should be the basis for deciding whether enrichment planting should be carried out or not. The objectives of the study were to assess the densities of commercial seedlings under Macaranga spp. and under other residual tree species and to collect information on natural regeneration in a logged-over area 20 years after harvesting. 


\title{
Materials and Methods
}

\author{
Site description
}

The study was carried out in a logged-over area in the ITCI concession in East Kalimantan, Indonesia $\left(1^{\circ} 16^{\prime} \mathrm{S}, 116^{\circ} 18^{\prime} \mathrm{E}\right)$ at an elevation of $230-300 \mathrm{~m}$ in an area with annual precipitation of 2000 to $2500 \mathrm{~mm}$. The area was logged with crawler tractors in 1976, 20 years prior to my study. Estimated timber volume harvested at that time was approximately $90-120 \mathrm{~m}^{3} / \mathrm{ha}$; 20 years after logging, the average canopy height was about $20-30 \mathrm{~m}$.

\section{Methods}

Densities of commercial seedlings $(<1.5 \mathrm{~m}$ tall) were estimated under patches of Macaranga trees and under other tree species. Under each type of canopy, 15 plots, 40 $\mathrm{m}^{2}$ each $(10 \times 4 \mathrm{~m})$ were randomly located.

\section{Data analysis}

Data were analyzed with MINITAB and Microsoft Excel software. Due to the nonnormal distributions of the data, a non-parametric test was used.

\section{Results}

The density of commercial seedlings under Macaranga was significantly higher than under other residual species (median $_{\text {Macaranga }}=0.35 / \mathrm{m}^{2} ;$ median $_{\text {Other }}=0.05 / \mathrm{m}^{2}, \mathrm{~N}_{\text {Maca- }}$ ranga $=15, \mathrm{~N}_{\text {Other }}=15, \mathrm{P}<0.01$, Table 1$)$. Densities of commercial tree seedlings under patches of Macaranga varied from $0.18-0.73$ seedlings $/ \mathrm{m}^{2}$, and from $0-0.28$ seedlings $/ \mathrm{m}^{2}$ under other species.. The average density of commercial seedling under Macaranga was 0.37 seedlings $/ \mathrm{m}^{2}$, whereas under other species it was 0.07 seedlings $/ \mathrm{m}^{2}$.

\section{Discussion}

My results indicate that the growth of commercial tree seedlings is influenced by gaps created by felled trees that are colonized by Macaranga trees. Light levels under Macaranga seemed greater than under other residual species. Under Macaranga, the commercial seedlings presumably have enough space and light to grow. Under residual species, in contrast, commercial seedling growth is likely to be reduced because of limitations of light and perhaps intense root competition.

Site conditions under Macaranga might be appropriate for commercial seedlings to regenerate, especially many dipterocarps. Some dipterocarps require intermediate light intensities and are called gap opportunists (Weidelt 1991). Results of shading trials with dipterocarp seedlings showed that the best growth of dipterocarps (as well as many other shade-tolerant species) is obtained under moderate shade (after Nicholson 1960 in Weidelt 1991). 
Table 1. Density of commercial seedlings under Macaranga and under other tree species in each $40 \mathrm{~m}^{2}$ plot (mean $\pm 1 \mathrm{SD}$ )

\begin{tabular}{|r|r|r|}
\hline No. & Macaranga & Other Species \\
\hline 1 & 18 & 3 \\
2 & 7 & 1 \\
3 & 29 & 7 \\
4 & 10 & 4 \\
5 & 9 & 11 \\
6 & 8 & 4 \\
7 & 15 & 0 \\
8 & 25 & 2 \\
9 & 17 & 1 \\
10 & 9 & 2 \\
11 & 27 & 1 \\
12 & 12 & 3 \\
13 & 7 & 1 \\
14 & 14 & 0 \\
15 & 16 & 2 \\
\hline X SD: & $14.87 \pm 7.26$ & $2.8 \pm 2.9$ \\
\hline
\end{tabular}

\section{Conclusion}

Regeneration of tropical trees depends on a variety of factors, including light availability. Based on this study, commercial seedling densities are high under the shade of Macaranga trees where light seems sufficient for their persistence.

\section{Acknowledgement}

I would like to thank to Dr. Plinio Sist for his comments on an earlier version of this manuscript. I also would like to thank all the instructors who helped me during this research workshop, and CIFOR, FAO, USAID, and the USDA Forest Service for providing me the opportunity to participate in this important event. Last but not least, I thank the ITCI Forest Concession for their hospitality and my fellow participants for their kindness and support.

\section{Literature Cited}

Bertault, J.G, and Sist, P. 1995. The effects of logging in natural forests. Bois et Forêts des Tropiques 25: 14-20. 
Nussbaum, R, Anderson, J. and Spencer, T. 1995. Effects of selective logging on soil characteristics and growth of planted dipterocarps seedling in Sabah. In: R.B. Primack and T.E. Lovejoy, Editors. Ecology, Conservation, and Management of Southeast Asia Rainforests. Yale University Press, New Haven, Connecticut, USA.

Pinard, M.A, Putz, F.E, Tay, J, and Sullivan, T.E. 1995. Creating timber harvest guidelines for a reduced-impact logging project in Malaysia. Journal of Forestry 93: 41-45.

Weidelt, J.H. 1991. Tropical Silviculture. Provisional Lecture Notes. Winter Semester. Gottingen University. Germany. 


\title{
MACARANGA TREE DENSITY VARIATION IN FELLING GAPS IN A LOGGED-OVER FOREST IN EAST KALIMANTAN, INDONESIA
}

\author{
R. P. Escobin \\ Forest Products Research and Development Institute, Department of Science and Technology, \\ College, Laguna, The Philippines \\ ESCOBIN, R. P., 1996. Macaranga tree density variation in felling gaps in a \\ logged-over forest in East Kalimantan, Indonesia. The density of Macaranga trees in \\ felling gaps in a logged-over forest in East Kalimantan, Indonesia was studied. Four \\ stumps were located and number of Macaranga trees were counted from the stump \\ area towards the fallen crown portion in $10 \mathrm{~m}$ wide plots extending to $30 \mathrm{~m}$ and di- \\ vided into 5-m segments. Regression analysis revealed that density of Macaranga \\ trees increased with the distance from the stump.
}

Keywords: Tropical rainforests - pioneer species - Macaranga spp. - felling gaps

\section{Introduction}

Timber harvesting in tropical rainforests unavoidably creates felling gaps that are favorable for the growth and development of pioneer trees such as Macaranga spp. According to Whitmore (1975), a bole of a single tree cuts only a narrow swathe through the forest, whereas the crown creates an opening of up to 0.04 ha. Having no commercial value, the Macaranga trees that develop in logging gaps are presently considered weed trees that may restrict the growth of the favored dipterocarp regeneration through competition for light, water and nutrients. Studies on densities of Macaranga in felling gaps could be important as indicators of forest disturbance and of the reproductive potential of commercial tree species.

\section{Materials and Methods}

\section{Site description}

This study was conducted in the timber concession of International Timber Corporation (ITCI) located in East Kalimantan, Indonesia $\left(1^{\circ} 16^{\prime} \mathrm{S}, 116^{\circ} 18^{\prime} \mathrm{E}\right)$. The site was logged in 1976, 20 years prior to this study. The annual precipitation in the area is about $2000-2500 \mathrm{~mm}$ and the elevation ranges from 230 to $300 \mathrm{~m}$.

\section{Data collection}

Tree stumps were located and the direction of fall was determined through examination of the undercut and felling cut. Starting at the stump and extending in the direction of tree fall, a $10 \mathrm{~m}$ wide plot was established that extended $30 \mathrm{~m}$ and was divided into $5 \mathrm{~m}$ intervals. For each $5 \mathrm{~m}$ interval the number of Macaranga spp. trees > $10 \mathrm{~cm} \mathrm{dbh}$ was recorded. 


\section{Data analysis}

A separate simple linear regression analysis was calculated for each stump examined. The mean of the slopes of the regression lines was then analyzed using a t-test to determine whether the mean slope differed from zero.

\section{Results}

Four stumps and associated gaps were located and studied. Graphical representation of the data (Figure 1) revealed that the variances were correlated with the means, so the data were log-transformed before analysis. The mean slope was significantly different from zero $(P<0.05, n=4)$. The regression equations obtained for the four stumps are as follows:

$\begin{array}{lll}\text { Stump1 } & \text { Density } 1=1.510+0.0685 \text { (Distance) } & \mathrm{P}<0.05 \\ \text { Stump 2 } & \text { Density } 2=0.040+0.0335 \text { (Distance) } & \mathrm{P}<0.05 \\ \text { Stump 3 } & \text { Density } 3=-0.077+0.0328 \text { (Distance) } & \mathrm{P}<0.05 \\ \text { Stump 4 } & \text { Density } 4=-0.250+0.3000 \text { (Distance) } & \mathrm{P}<0.10\end{array}$

\section{Discussion}

The results of the study suggests that the density of Macaranga spp. increases with distance from the stump in the direction of tree fall. The large variation observed may be attributed to the morphology of the felled trees which have their widest area in the crown portion. As the tree is felled, more damage is inflicted by the branch and crown portions as compared to the stem and butt portions.

\section{Implications}

According to Putz (1990), generally about half the damage to residual trees in logging areas is inflicted during felling operations. It is therefore very important in sustainable forest management to direct the fall of trees in such a way that damage to potential crop trees is kept to a minimum. A tree felled on other trees increases the area of felling gap and thereby increases the chances of pioneer tree or vine infestation. Moreover, a tree felled in the wrong direction with respect to skidtrails makes skidding difficult and causes more damage and larger gaps that are colonized by Macaranga trees. The competitive ability of Macaranga is well known (e.g., Guzmán 1996; Dolom 1996; Pinard et al. 1995). Under high light conditions the species can easily outgrow other trees by overtopping them with their large broad leaves. The findings of this study support Whitmore (1990) and Pinard and Putz (1996) who state that large gaps increase the chances of pioneer tree infestation that may restrict the growth development of potential crop trees through competition.

For sustainable forest management to succeed, researchers agree that reducing logging damage and the sizes and densities of forest gaps through a good management plan and careful practices is needed (Dykstra and Heinrich 1996, Pinard and Putz 1996, Pinard et al. 1995). 


\section{Conclusion}

Based on the results of this study the density of Macaranga spp. increases with distance from stumps following the direction of tree fall. The pattern is attributed to tree morphology insofar as a fallen tree's greatest area is at the level of the crown.

\section{Acknowledgment}

The author wishes to thank his instructors for the motivation and assistance extended to him in the conduct of this study. Thanks are also due to the management of the International Timber Corporation Indonesia (ITCI) for accommodation and assistance in the data gathering phase in East Kalimantan, Indonesia. Sincere thanks are also due to CIFOR, FAO, USAID, and the USDA Forest Service for accepting my application to participate in this training seminar/workshop.

\section{References}

Dolom, P. 1996. Effect of nearest neighbour tree species on Macaranga diameter in a logged forest in Indonesia. In: Research Methods for Reduced-Impact Logging: Workshop Results. F.E. Putz, Elias, P. Sist, D. Dykstra and R. Heinrich, editors. CIFOR Special Publication.

Dykstra, D.P. and R. Heinrich. 1996. FAO Model Code of Forest Harvesting Practice. Food and Agriculture Organization of the United Nations, Rome. 85 p.

Guzmán, R. 1996. Relation between tree density and maximum diameter of Macaranga species in different sized gaps 20 years after logging in East Kalimantan, Indonesia. In: Research Methods for Reduced-Impact Logging: Workshop Results. F.E. Putz, Elias, P. Sist, D. Dykstra and R. Heinrich, editors. CIFOR Special Publication.

Pinard, M.A. and F.E. Putz. 1996. Retaining forest biomass by reducing logging damage. Biotropica 28.

Pinard, M.A., F.E. Putz, J. Tay, and T.E. Sullivan, 1995. Creating timber harvest guidelines for a reduced-impact logging project in Malaysia. Journal of Forestry 93: 41-45.

Putz, F.E. 1994. Approaches to sustainable forest management, CIFOR Working Paper No.4.

Whitmore, T.C. 1975: Tropical Rainforests of the Far East. Oxford University Press, $282 \mathrm{p}$.

Whitmore, T.C. 1990. An Introduction to Tropical Rain Forests. Clarendon Press. Oxford $226 \mathrm{p}$. 


\title{
EFFECTS OF DISTURBANCE ON PLANT FUNCTIONAL ATTRIBUTES IN A LOGGED FOREST IN BORNEO: PHOTOSYNTHETIC STEMS AND LEVELS OF FURCATION
}

\author{
Elizabeth A. Zweede
}

Department of Botany, University of Florida, Gainesville, Florida, U.S.A.

\begin{abstract}
ZWEEDE, E. A., 1996. Effects of disturbance on plant functional attributes in a logged forest in Borneo: photosynthetic stems and levels of furcation. Research was conducted 20 years after logging in East Kalimantan to assess whether disturbances near logging roads increase the proportion of trees with photosynthetic stems and furcation levels. There was no correlation between distance to the road $(0-40 \mathrm{~m})$ and the two plant attributes measured. However, within $20 \mathrm{~m}$ of the road, furcation and proportion of photosynthetic stems decreased as a function of distance. Plant functional attributes (morphological features assumed to adapt to changes in the physical environment) can be used as indicators of disturbances such as logging.
\end{abstract}

Key words: plant functional attributes - furcation index - photosynthetic stems - logging

\section{Introduction}

Conventional selective logging in the tropics can cause high levels of damage to the residual forest (Pinard and Putz 1996). After logging, the remaining trees may be subjected to many environmental changes, such as increased light intensity, increased soil temperature, and invasion by pioneer species (Smith 1986). These changes can alter species composition of the forest (Johnson and Cabarle 1993) as well as characteristics of the vegetation and individual trees (Gillison 1988). It is important to assess the extent and degree of disturbance to residual stands so that recommendations can be made for reducing this disturbance and so that forest health may be assessed.

Plant functional attributes (PFA) are morphological features that are assumed to be adapted to specific environments (Gillison 1996). Some examples include leaf size, leaf inclination, leaf form, life form, root type, and chlorotype. It is thought that these features reflect a relationship between the plant and its environment. This system of classification is not species specific and requires no taxonomic identification. Gillison (1996) has shown that this way of looking at the forest is generalizable across continents and that PFAs can serve as a tool to facilitate research in an area where taxonomic information is limited.

Certain plant attributes change with the onset of disturbance. One specific example of using PFAs in measuring the impacts of disturbance is Gillison's (1996) data on reduced-impact versus conventional logging in Sabah Malaysia. Although the two areas were logged at similar intensities, they were distinguishable on the bases of their PFAs. He suggested that PFAs can be used to assess logging disturbance and indicate whether residual stands are recuperating from logging damage. 
In this study, two PFAs were used as possible indicators of disturbance: proportion of trees with photosynthetic stems and relative heights of branching of the main stem (furcation index). The study site was a forest in East Kalimantan that was logged 20 years prior to this study and the damage to be assessed was associated with a main logging road. I assumed that vegetation closest to the road was most affected by the disturbance and therefore would show increases in levels of furcation and an abundance of trees with photosynthetic stems.

\section{Materials and methods}

\section{Site description}

The study area was a lowland forest in East Kalimantan, Indonesia $\left(1^{\circ} 16^{\prime} \mathrm{S}\right.$, $\left.116^{\circ} 18^{\prime} \mathrm{E}\right)$, at an elevation of $230-300 \mathrm{~m}$, and with an annual rainfall of about 2500 $\mathrm{mm}$. The forest is part of the ITCI concession and was logged in 1976, 20 years prior to this study. The study site slopes down from the road at $18 \%$ and faces southeast. The forest was originally dominated by Dipterocarpaceae, but twenty years after logging, 50\% of the basal area of the forest was pioneer species (e.g., Macaranga, Octomeles, Neonauclea, Anthocephallus, and Tetrastigma; Tun 1996).

\section{Methods}

The study area extended $100 \mathrm{~m}$ along the main logging road and $40 \mathrm{~m}$ into the adjacent forest. At each randomly located point $(0-40 \mathrm{~m}$ from the road; $\mathrm{N}=13)$, ten trees > $5 \mathrm{~cm}$ dbh were measured along a $2 \mathrm{~m}$ wide transect parallel to the road. The presence of photosynthetic bark and furcation level were recorded for each individual; when possible, the trees were identified. Furcation level was determined by finding the point at which the main axis split, and taking the distance from that point to the top of the crown. This distance was then expressed as the percent of the total height of the tree.

\section{Results and Discussion}

Non-parametric analysis revealed no correlation between either proportion of photosynthetic stems and distance from the road (Figure $1 ; r_{s}=-0.65$ ) or average furcation and distance from the road (Figure $2 ; r_{s}=-0.51$ ).

Observation in the field and inspection of the data suggested a strong trend up to about $20 \mathrm{~m}$ from the road. In contrast, between 20 and $40 \mathrm{~m}$ the furcation index and presence of photosynthetic stems became more variable. This increase in variation could be due to the presence of felling gaps or perhaps changes in species composition. Near the road there was a predominance of Piper aduncum, Urticaceae, and Tetrastigma spp., whereas beyond $20 \mathrm{~m}$, Macaranga spp. and Anthocephallus spp. predominated. Disturbance associated with the road, especially as it relates to light availability, may only have had an effect up to $20 \mathrm{~m}$ into the forest. With these observations in mind, simple linear regressions were performed on the data for trees within $20 \mathrm{~m}$ of the road (Table 1). 
PROPORTION OF PHOTOSYNTHETIC STEMS

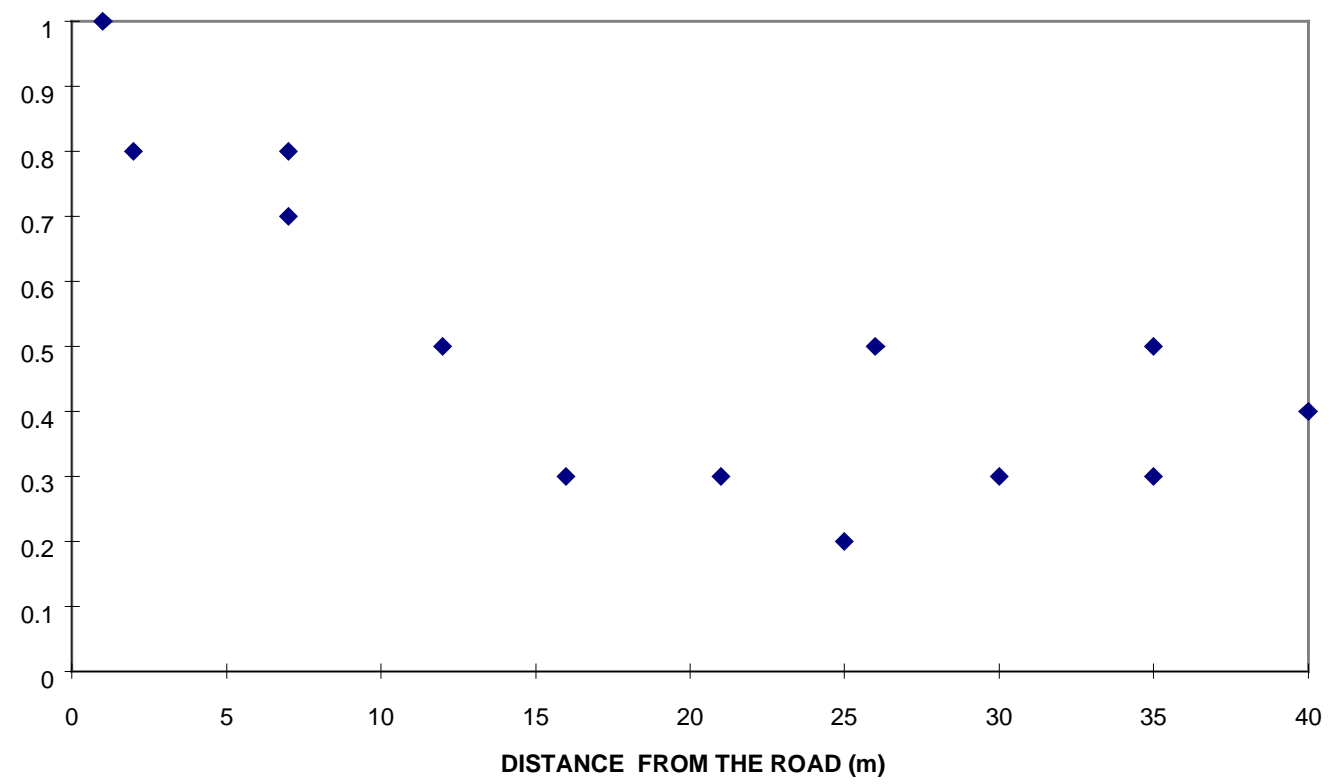

Figure 1. Proportion of trees with photosynthetic stems as a function of distance from the road.

AVERAGE FURCATION INDEX

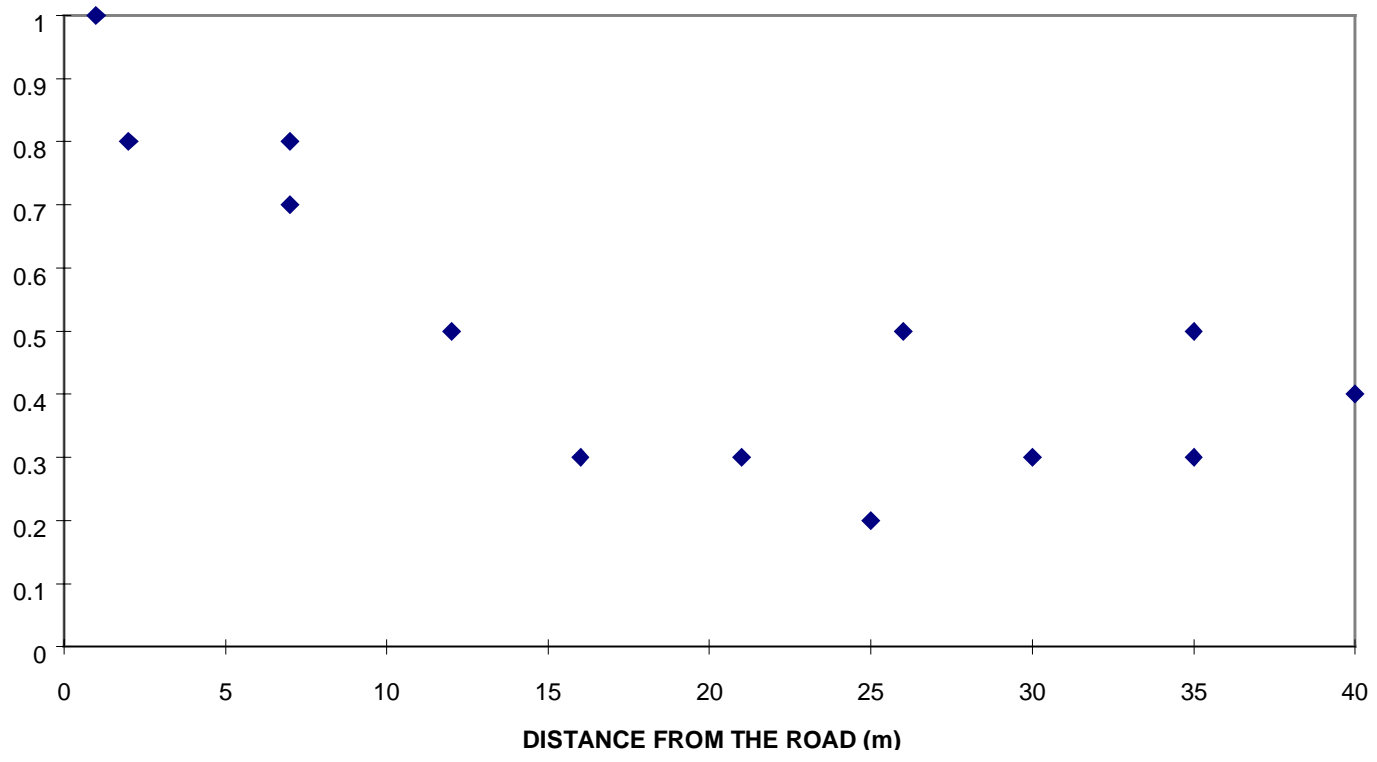

Figure 2. Furcation index as a function of distance from the road. 
Table 1. Tests of two plant functional attributes as a function of distance (D) from the road $(0 \leq \mathrm{D} \leq 20 \mathrm{~m} ; \mathrm{N}=6)$.

\begin{tabular}{|l|c|l|l|}
\hline Attribute Measured & \multicolumn{3}{|c|}{ Statistical Analysis Results } \\
\hline $\begin{array}{l}\text { Percent of trees with } \\
\text { photosynthetic stems }\end{array}$ & $\begin{array}{c}=0.994-0.0414(\mathrm{D}) \\
\mathrm{s}=0.006\end{array}$ & $\mathrm{P}<0.002$ & $\mathrm{R}^{2}=92.0 \%$ \\
\hline Average furcation index & $\begin{array}{c}=55.2-3.27(\mathrm{D}) \\
\mathrm{s}=0.48\end{array}$ & $\mathrm{P}<0.002$ & $\mathrm{R}^{2}=92.0 \%$ \\
\hline
\end{tabular}

\section{Conclusion}

I hypothesized that compared to the forest interior, trees closer to the road would have higher levels of furcation and a higher proportion would have photosynthetic stems. However, this study revealed no overall correlation between distance from the main logging road and the two plant functional attributes measured. In contrast, when I restricted my analysis to the area most affected by the road $(0-20 \mathrm{~m})$, there was a rapid decline in the proportion of trees with photosynthetic stems and in their levels of furcation.

To use plant functional attributes as indicators of environmental disturbances, like logging, it is important to understand how these features are modified with changes in the physical environment. If we can understand, for example, how certain plant features change with different levels of stress, then perhaps PFAs can be used to quickly assess the health of a residual forest.

\section{Acknowledgments}

I would like to thank CIFOR, FAO, USAID, and the USDA Forest Service for sponsoring my participation in this training seminar. I am very grateful to the instructors: F.E. Putz, P. Sist, D. Dykstra, R. Heinrich, Elias, A. Gillison, R. Prabhu, and L.A. Newell; whose energetic efforts made the seminar an informative and practical learning experience. I would like to extend a special thanks to the staff at CIFOR for facilitating the seminar, and to the people at the ITCI concession for their hospitality during our field work in East Kalimantan. Finally, I wish to give warm thanks to my friends from the seminar, who made the whole experience enjoyable.

\section{References}

Gillison, A.N. 1988. A plant functional proforma for dynamic vegetation studies and natural resource surveys. Technical Memorandum - CSIRO Institute of Natural Resources and Environment, Division of Water Resources.

Gillison, A.N. The modus line: an equilibrium model for plant species and plant functional types. Nature (in review). 
Johnson, N. and Carbarle, B. 1993. Surviving the Cut: Natural Forest Management in the Humid Tropics. World Resources Institute. Washington, D.C.

Pinard, M.A. and Putz, F.E. 1996. Retaining forest biomass by reducing logging damage. Biotropica 28.

Smith, D.M. 1982. Principles of Silviculture. Academic Press, Orlando, Florida, USA.

Tun, T. 1996. Basal area of pioneer and primary tree species 20 years after logging in East Kalimantan, Indonesia. In: Research Methods for Reduced-Impact Logging: Workshop Results. F.E. Putz, Elias, P. Sist, D. Dykstra, and R. Heinrich, editors. CIFOR Special Publications. 


\title{
INFLUENCE OF NEIGHBOUR TREES ON THE DIAMETER OF FOCAL TREES IN LOGGED-OVER DIPTEROCARP FOREST, EAST KALIMANTAN, INDONESIA
}

\author{
Ismoyo
}

PT. Sumalindo Lestari Jaya, Samarinda, East Kalimantan, Indonesia

\begin{abstract}
ISMOYO, 1996. Influence of neighbour trees on the diameter of focal trees in logged-over dipterocarp forest, East Kalimantan, Indonesia. Tree diameter was predicted to be a function of the total basal area and the distance to the 4 nearest neighbour trees. Linear regression and multiple regression analyses showed that the relationship between the diameter of focal trees and the basal area and the distance to the 4 nearest neighbour trees is not statistically significant.
\end{abstract}

Keywords: Tropical rain forest - focal trees - neighbour trees - diameter - basal area

\section{Introduction}

In dipterocarp forests, tree growth rates vary greatly between individuals. The exact location of the trees is determined by several factors such as the position of the mother tree, competition by other trees, and logging disturbances. The total basal area of all trees, or of specified classes of trees, per unit area is a useful characteristic of a forest stand. For example, basal area is directly related to stand volume and is a good measure of stand density (Husch et al.1923). The growth of individual trees is influenced by inter-tree competition. Trees in dense forest stands are in competition for light, nutrients, water, and carbon dioxide. In the angle-summation method (Spurr 1962) a point or tree is chosen on which we wish to determine the degree of competition from surrounding trees. This method is useful in studies on the correlation between tree growth and density around that tree, the correlation between establishment of natural regeneration and point density, and the selection of plus trees in tree improvement research (Husch et al. 1923). To determine the influence of neighbour trees on the diameter of focal trees, research was conducted in a loggedover dipterocarp forest to identify the relationship between diameter of focal trees and the basal area and distance to the four nearest neighbour trees.

\section{Materials and Methods}

\section{Site Description}

The location of this study was a logged-over dipterocarp forest in the concession area of PT. International Timber Corporation Indonesia, East Kalimantan, Indonesia $\left(1^{\circ} 16^{\prime} \mathrm{S}, 116^{\circ} 18^{\prime} \mathrm{E}\right)$. This area was logged 20 years ago, the annual precipitation is 2000-2500 $\mathrm{mm}$, and the elevation is $230-300 \mathrm{~m}$ above sea level. 


\section{Methods}

Focal trees were selected at random and the four nearest neighbour trees which had the same or larger diameters were measured at breast height $(1.3 \mathrm{~m}$ above the ground; $\mathrm{dbh}$ ). The distance to each of the nearest neighbour trees from the focal tree was measured.

\section{Data analysis}

I used simple linear and multiple regression analyses to examine the relationships between diameter of focal trees and the total basal area and distances of four nearest neighbour trees. The hypotheses tested was that the diameter of focal trees decreases with increased basal area and increases with distance to the four nearest neighbour trees.

\section{Results}

The results of data analysis using simple and multiple linear regression shows that the relationship between the diameter of the focal trees and the basal area and distances to four neighbour trees was not significant at the 95\% confidence level (Table 1).

Table 1. Focal tree diameter and neighborhood characteristics.

\begin{tabular}{|c|c|c|}
\hline $\begin{array}{c}\text { Diameter of Focal Tree } \\
(\mathbf{c m})\end{array}$ & $\begin{array}{c}\text { Sum of Basal Areas } \\
\mathbf{( m}^{\mathbf{2}} \mathbf{n}\end{array}$ & $\begin{array}{c}\text { Sum of Distance } \\
(\mathbf{m})\end{array}$ \\
\hline 17 & 0.391 & 15.55 \\
\hline 15 & 1.136 & 21.38 \\
\hline 11 & 0.340 & 11.95 \\
\hline 8 & 0.161 & 9.59 \\
\hline 28 & 0.697 & 11.05 \\
\hline 34 & 0.623 & 20.82 \\
\hline 21 & 0.607 & 7.63 \\
\hline 10 & 0.419 & 15.55 \\
\hline 19 & 0.699 & 13.83 \\
\hline 7 & 0.818 & 17.86 \\
\hline 5 & 1.421 & 12.97 \\
\hline 4 & 0.720 & 13.44 \\
\hline 8 & 1.234 & 13.84 \\
\hline 6 & 2.943 & 16.42 \\
\hline 10 & 1.468 & 19.00 \\
\hline
\end{tabular}


The following are the results of the regression analyses:

$$
\begin{aligned}
& \text { Diameter }=17.4-4.19(\text { Basal Area }) \\
& \mathrm{s}=8.630, \mathrm{R}^{2}=10.8 \%, \mathrm{t}=-1.25, \mathrm{P}=0.235 \\
& \text { Diameter }=10.7+0.196(\text { Distance }) \\
& \mathrm{s}=9.095, \mathrm{R}^{2}=0.8 \%, \mathrm{t}=0.32, \mathrm{P}=0.756 \\
& \text { Diameter }=11.1-5.07(\text { Basal Area })+0.476(\text { Distance }) \\
& \mathrm{s}=8.774, \mathrm{R}^{2}=14.8 \%, \mathrm{t} \text { Basal Area }=-1.40, \mathrm{t}_{\text {Distance }}=0.76, \mathrm{P}_{\text {Basal Area }}=0.186, \\
& \mathrm{P}_{\text {Distance }}=0.462
\end{aligned}
$$

\section{Discussion}

The regression analyses indicate no statistically significant relationship between the diameter of focal trees and the basal area and distances of four nearest neighbour trees. The total basal area of four nearest neighbour trees can be the same or larger as four times the basal area of the focal tree. Increased diameter of the focal tree does not always imply an increased basal area of neighbour trees. Increased diameter of the focal tree was not always accompanied by increasing distance to neighbour trees.

\section{Conclusion}

There was no statistically significant influence of neighbour trees on the diameter of focal trees in a logged-over dipterocarp forest. The diameter of the focal tree could not be expressed as a function of basal area and distance to the four nearest neighbour trees.

\section{Acknowledgments}

The author would like to thank CIFOR, FAO, USAID, and the USDA Forest Service for allowing him to participate in the workshop on Reduced-Impact Timber Harvesting and Natural Forest Management. Special thanks to all the instructors who motivated me to conduct this research. Also thanks to PT. ITCI for their hospitality and assistance during data gathering in the field.

\section{Reference}

Husch, B. et al. 1923. Forest Mensuration. Krieger Publishing Company, Malabar, Florida. 


\title{
LOGGING TIME STUDIES: OVERVIEW OF GROUP PROJECTS
}

\author{
Francis E. Putz \\ Center for International Forestry Research (CIFOR), Bogor, Indonesia
}

and

Rudolf Heinrich

Forestry Department, Food and Agriculture Organization of the United Nations, Rome, Italy

\section{Introduction}

To familiarize workshop participants with timber harvesting practices in PT. ITCI in East Kalimantan and to acquaint them with research methods used for time studies, we conducted pilot projects on timber yarding and log landing activities. Allocating time during the workshop for these studies seemed warranted because recommended changes in timber harvesting practices are most likely to be implemented if they are based on thorough analyses of efficiency, of which time studies are an important component.

As an introduction to time studies, all participants collected data on the loading of a timber lorry, from the point at which it entered the log landing to its departure 18.5 minutes later with seven logs amounting to 45 cubic meters of timber. The participants were divided into groups of two, and each pair was assigned the task of recording the time used for all loading activities, using either continuous time or activity sampling measurements (for the latter, samples at 30-second or 1-minute intervals were used). Activities recorded included truck positioning, trailer setting, log manipulation, log loading, tightening of binders on the loaded logs, avoidable delays, and unvoidable delays. Overall the operation appeared extremely efficient. The skill of the front-end loader operator was particularly noteworthy.

The exercise in time studies revealed to the participants the value of good communication between research teams and the need to agree on activity definitions before data collection commences. Overall, the data from the groups which recorded activities in continuous time were similar to those from groups that used activity sampling at 30-second and 1-minute intervals. Activity sampling, however, resulted in lost information about activities that occupied only brief periods of time.

Our hosts provided us the opportunity to witness both reduced-impact and conventional felling and yarding operations. When we arrived at the demonstration site we were met by forest technicians employed by the concessionaire who explained the usefulness of their 100\% stock maps (all trees $>20 \mathrm{~cm} \mathrm{dbh}$ ), how roads and skidtrails should be laid out, and how felling directions are determined. We then went into the forest to inspect a tree that was to be felled and discussed in more detail the potential benefits of training in directional felling. After the tree was felled (a $12 \mathrm{~m}^{3}$ dipterocarp that fell exactly in the intended direction), we went back into the forest to observe the bucking and yarding operations. The log was measured by two 
of the visiting forest technicians and bucked by the sawyer into two logs. Although the crawler tractor (Caterpillar D6H) drove up next to the logs rather than using the winch to pull the logs to a pre-marked skidtrail, the operator was cautious not to cause unnecessary damage to the residual forest. He encountered some trouble skidding the larger of the two logs up the $30 \%$ slope to the roadside and was forced to leave the log behind, drive up the hill, set the blade, dig in by spinning the bulldozer's tracks, and then winch the log up the hill. This operation caused considerable damage to the skidtrail and a cross drain will need to be installed to prevent soil erosion.

In the afternoon we split into two groups to conduct time studies on two different crawler tractors. One group that travelled about $3 \mathrm{~km}$ to an area where conventional timber yarding was underway had the opportunity to witness first hand the unnecessary damage associated with unplanned logging operations carried out by unsupervised workers paid on the basis of log volumes delivered to the roadside with little incentive to reduce damage to soil or the residual stand. Although the presence of tagged trees gave evidence of stock mapping, the tractor driver had no maps nor apparently any clear idea where the logs to be yarded were located in the forest. Communications between the driver and his assistant seemed particularly bad and were in part responsible for the unnecessary opening of $85 \mathrm{~m}$ of a $240 \mathrm{~m}$ long skidtrail.

During the evening discussion session, time data from the different groups were compared. The general consensus was that continuous time monitoring was more accurate and informative than activity sampling at 30-second and 1-minute intervals. The value of applying reduced-impact logging methods was also emphasized during the discussion. Overall the experience of collecting detailed quantitative data on logging activities seemed well worthwhile. 


\section{APPENDIX 1 \\ Alphabetical List of Participants}

\begin{tabular}{|c|c|}
\hline Name & Contact information \\
\hline Ahmad Budiaman & $\begin{array}{l}\text { Bogor Agricultural University } \\
\text { Faculty of Forestry } \\
\text { Kampus IPB } \\
\text { P.O. Box 168 } \\
\text { Bogor 16001, INDONESIA } \\
\text { Telephone: } \quad+62251621285 \\
\text { Fax: } \quad+6225162156 \\
\text { E-mail: } \quad \text { jthh-ipb@indo.net.id }\end{array}$ \\
\hline Charles Dei-Amoah & $\begin{array}{l}\text { Planning Branch } \\
\text { Forestry Department } \\
\text { P.O. Box 1917 } \\
\text { Kumasi, GHANA } \\
\text { Telephone: } \quad+2335123366 \\
\text { Fax: } \quad+2335122687 \\
\end{array}$ \\
\hline Priscila C. Dolom & 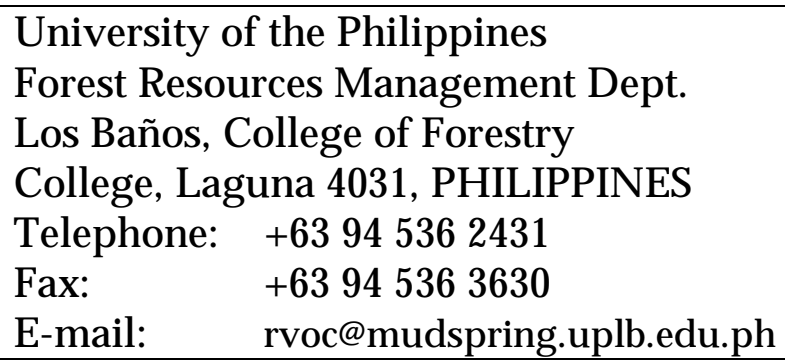 \\
\hline Ramiro P. Escobin & $\begin{array}{l}\text { Forest Products R\&D Institute } \\
\text { College, Laguna 4031, PHILIPPINES } \\
\text { Telephone: } \quad+63945362377 \\
\text { Fax: } \quad+63945363630\end{array}$ \\
\hline Rudy A. Guzmán Gutiérrez & 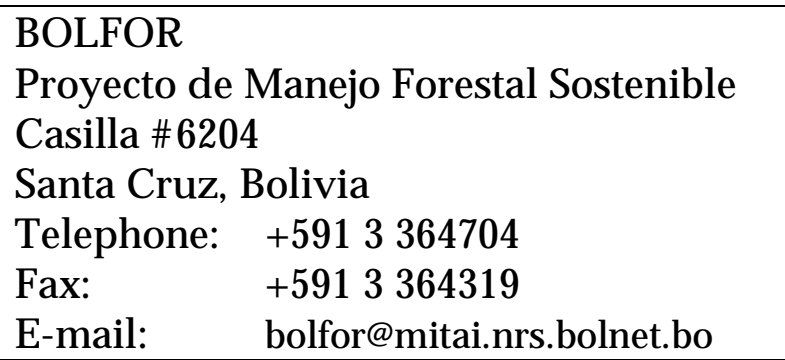 \\
\hline Ismoyo & 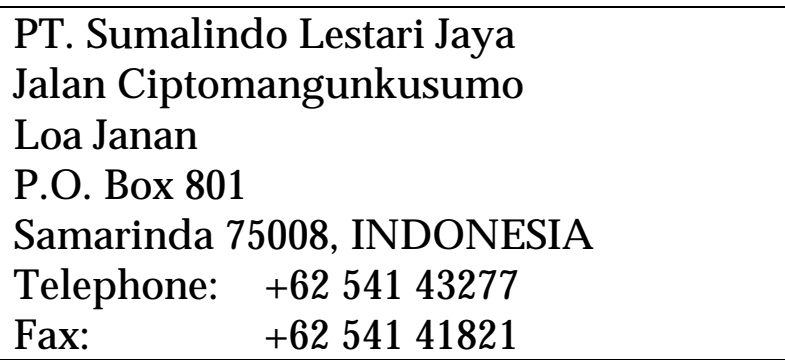 \\
\hline
\end{tabular}

[continues on the following page] 


\section{Alphabetical List of Participants (continued)}

\begin{tabular}{|c|c|}
\hline Name & Contact information \\
\hline Lopachoke Thawornwong & 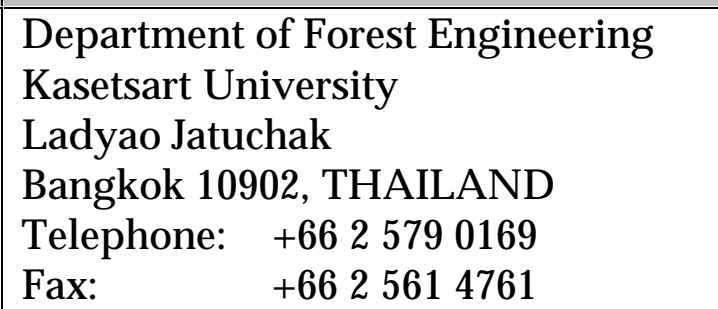 \\
\hline Mai Van Thanh & $\begin{array}{l}\text { Forest Science Institute of Vietnam } \\
\text { Chem Tuliem, Hanoi } \\
\text { VIETNAM } \\
\text { Telephone: } \quad+8448362251 \\
\text { Fax: } \quad+8448345722\end{array}$ \\
\hline Lorentz Marpaung & 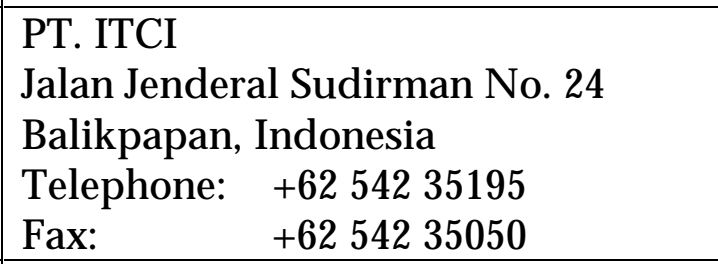 \\
\hline Muhammad Farid Bin Abdul Rashid & $\begin{array}{l}\text { FRIM } \\
\text { Kepong 52109, Kuala Lumpur } \\
\text { MALAYSIA } \\
\text { Telephone: } \quad+6036302320 \\
\text { Fax: } \quad+6036367753 \\
\text { E-mail: } \quad \text { farid@frim.gov.my }\end{array}$ \\
\hline Herman Prayudi & $\begin{array}{l}\text { APHI } \\
\text { Manggala Wanabakti Building } \\
\text { Block IV, 9th Floor, Wing B } \\
\text { Jalan Jenderal Gatot Subroto } \\
\text { Senayan, Jakarta 10270, INDONESIA } \\
\text { Telephone: } \quad+62215737036 \\
\text { Fax: } \quad+62214732564 \\
\text { E-mail: } \quad \text { aphijkt@idola.net.id }\end{array}$ \\
\hline Ayi Suyana & $\begin{array}{l}\text { Forestry Research Institute } \\
\text { Jalan Pandan Wangi } \\
\text { P.O. Box } 1206 \\
\text { Samarinda, INDONESIA } \\
\text { Telephone: } \quad+6254142298 \text { / } 31501\end{array}$ \\
\hline Mohd. Daud Tampokong & $\begin{array}{l}\text { Innoprise Corporation Sdn. Bhd. } \\
\text { P.O. Box } 60793 \\
\text { 91019 Tawau, Sabah, MALAYSIA } \\
\text { Telephone: } \quad+6089772939 \\
\text { Fax: } \quad+6089763192\end{array}$ \\
\hline
\end{tabular}

[continues on the following page] 


\section{Alphabetical List of Participants (continued)}

\begin{tabular}{|c|c|}
\hline Name & Contact information \\
\hline U Tin Tun & 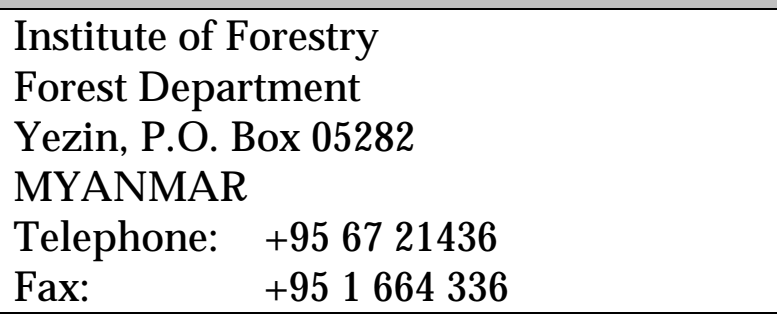 \\
\hline Dar-Hsiung Wang & $\begin{array}{l}\text { Taiwan Forestry Research Institute } \\
\text { Division of Forest Management } \\
\text { 53 Nan-Hai Road } \\
\text { Taipei, Taiwan, Republic of China } \\
\text { Telephone: + +886 } 23110061 \\
\text { Fax: } \quad+88623754216 \\
\text { E-mail: } \quad \text { darhsiung.wang@dds.com.tw }\end{array}$ \\
\hline U Ohn Win & 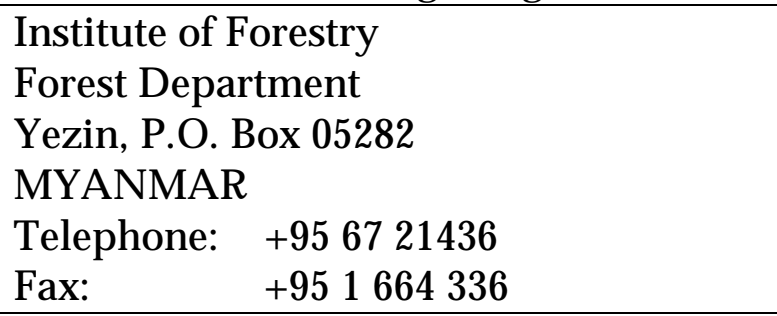 \\
\hline Elizabeth A. Zweede & $\begin{array}{l}\text { Department of Botany } \\
\text { University of Florida } \\
\text { Gainesville, FL 32611, U.S.A. } \\
\text { Telephone: } \quad+13523921468 \\
\text { Fax: } \quad+13523923993 \\
\text { E-mail: } \quad \text { zweede@nerum.nerdc.ufl.edu }\end{array}$ \\
\hline
\end{tabular}




\section{APPENDIX 2 \\ Alphabetical List of Instructors}

\begin{tabular}{|l|l|}
\hline Name & Contact information \\
\hline Dennis P. Dykstra & CIFOR \\
Deputy Director General for Research & P.O. Box 6596 JKPWB \\
& Jakarta 10065, Indonesia \\
& Telephone +62 251 343 652 \\
& Fax: +62 251 326 433 \\
E-mail: d.dykstra@cgnet.com
\end{tabular}

[continues on the following page] 


\section{Alphabetical List of Instructors (continued)}

\begin{tabular}{|l|l|}
\hline Name & Contact information \\
\hline $\begin{array}{l}\text { Francis E. Putz } \\
\text { Professor of Botany and Forestry }\end{array}$ & Department of Botany \\
Senior Associate, CIFOR & University of Florida \\
& 200 Bartram Hall \\
& Gainesville, FL 32611-2009, U.S.A. \\
& Telephone: +1 352 392 1486 \\
& Fax: $\quad+13523923993$ \\
& E-mail: fep@botany.ufl.edu \\
\hline Plinio Sist & CIFOR \\
Scientist, Natural Forest Management & P.O. Box 6596 JKPWB \\
& Jakarta 10065, Indonesia \\
& Telephone: +62 251 343 652 \\
& Fax: $\quad$ +62 251 326 433 \\
& E-mail: p.sist@cgnet.com \\
\hline
\end{tabular}




\section{APPENDIX 3 \\ Workshop Schedule}

\section{Sunday, 14 July 1996}

(All day) Arrival of participants

19:00 Group dinner with instructors and their spouses, Pangrango Hotel

\section{Monday, 15 July 1996}

08:00 - 09:00 Welcome and introduction to the course

D. Dykstra, Deputy Director General for Research, CIFOR; F. Putz, CIFOR and University of Florida; R. Heinrich, FAO

09:00 - 12:00 Statistics and experimental design workshop (F. Putz)

13:00 - 17:00 Formulation of testable hypotheses; analysis of data

20:00 FAO Model Code of Forest Harvesting Practices (R. Heinrich), Pangrango Hotel meeting room

\section{Tuesday, 16 July 1996}

08:00 - 12:00 Effects of logging on soil; basic research methods (F. Putz)

Independent research on soil compaction, water infliltration, erosion

13:00 - 16:00 Data analysis

16:00 - 17:30 Oral presentation of results (10 minutes per team)

17:30 - 18:30 Lecture on stand damage and regeneration in Kiani Lestari (Elias)

\section{Wednesday, 17 July 1996}

08:00 - 12:00 Field research techniques, plot establishment, tree heights, surveying techniques, canopy cover, slope corrections (Elias)

13:00 - 17:00 Workshop on analysis of permanent sample plot data (D. Dykstra, F. Putz, P. Sist)

17:00 - 18:00 STREK Project (P. Sist)

\section{Thursday, 18 July 1996}

08:00 - 10:00 Plant Functional Attributes (A. Gillison)

10:00 - 12:00 Analysis of permanent plot data (D. Dykstra, P. Sist, F. Putz, Elias)

13:00 - 15:00 Data analysis (continued)

15:00 - 18:00 Oral presentations and discussion of growth and yield analyses 


\section{Friday, 19 July 1996}

08:00 - 10:00 Harvesting methods, roads, and landings (R. Heinrich)

10:00 - 11:30 Reduced-Impact Logging (RIL) Project in Malaysia (F. Putz)

11:30 - 12:00 Awareness of issues related to harvesting and forest management (L. Newell)

13:00 - 14:00 Weed ecology and responses to poor harvesting/management practices (F. Putz)

14:00 - 15:30 Certification: background and research issues (R. Prabhu)

15:45 - 17:00 Time and motion studies (D. Dykstra)

\section{Saturday, 20 July 1996}

08:30 - 12:00 Bogor Botanical Garden

12:00 - 13:00 Lunch, Pangrango Hotel

13:00 - 17:00 Jakarta - Mini Indonesia Park, shopping

19:00 Culture night, Oasis Restaurant, Jakarta

Overnight in Bandara Hotel near Sukarno-Hatta International Airport

\section{Sunday, 21 July 1996}

09:40

GA 512, Jakarta to Balikpapan

Visit to Wanariset Research Center

Overnight in Dusit Inn

\section{Monday, 22 July 1996}

06:30 - 07:30 Travel from Dusit Inn to ITCI concession by bus and boat

07:30 - 08:30 General orientation to ITCI (Mr. Suwardi Suwasa)

08:30 - 09:30 Tropenbos system for forest harvest planning (Mr. Bambang)

09:30 - 10:30 Discussion

10:30 - 12:00 Tours of the sawmill, moulding plant, and plywood factory

13:00 - 17:00 Visit to logged-over forest

21:00 Discussion of factors influencing the adoption of research-based recommendations

Overnight at PT. ITCI Timber Concession Guest House 


\section{Tuesday, 23 July 1996}

07:30 - 17:30 Visit to logging area: time and motion studies, logging damage assessment, measurement of logging residues, gap sizes, etc.

20:00 Discussion of field observations

Overnight at ITCI Concession Guest House

Wednesday, 24 July 1996

07:30 - 17:30 Independent research in logged-over forest on skid trails, soil conditions, weeds, tree damage, etc.

Overnight at ITCI Concession Guest House

\section{Thursday, 25 July 1996}

07:00 ITCI to Balikpapan airport

09:20 GA 541, Balikpapan to Jakarta

10:20 Arrival in Jakarta; bus to Bogor

13:00 - 17:30 Data analysis, preparation of oral presentations, first drafts of manuscripts due (note: manuscripts will be prepared in accordance with the "Instructions to Authors" of the Journal of Tropical Forest Science).

\section{Friday, 26 July 1996}

08:00 Preparation of oral and written presentations

14:15 - 17:15 Symposium (8 minutes per speaker)

19:00 Banquet at Bogor Lakeside (bus departs Pangrango Hotel at 18:30)

\section{Saturday, 27 July 1996}

09:00 - 12:00 Final manuscripts due (on paper and diskette); return of all equipment

12:00 Departure of participants after delivery of manuscripts 


\section{APPENDIX 4 List of distributed materials}

Alder, D. and T.J. Synnott. 1992. Permanent Sample Plot Techniques for Mixed Tropical Forest. Tropical Forestry Papers 25, Oxford Forestry Institute.

Bertault, J-G. and P. Sist. 1995. Impact de l'exploitation en forêt naturelle. Bois et Forêt des Tropiques 245:5-20.

Dykstra, D. P. 1996. Introduction to growth and yield modelling (unpublished lecture notes).

Dykstra, D. P. and R. Heinrich. 1996. FAO Model Code of Forest Harvesting Practice. Food and Agriculture Organization of the United Nations, Rome. 85 p.

Elias, 1996. Field research techniques and permanent plot establishment in tropical natural forest (unpublished lecture notes).

Elias, 1996. Stand damage and regeneration in forest concession areas of P.T. Kiani Lestari and P.T. Narkota Rimba, East Kalimantan, Indonesia (unpublished lecture notes).

Ghana Forest Department. 1992. Logging Manual. Forestry Department, Kumasi, Ghana.

Johnson, N. and B. Cabarle. 1993. Surviving the Cut. World Resources Institute, Washington, DC.

Journal of Tropical Forest Science. 1996. Guide to authors.

Nussbaum, R., J. Anderson, and T. Spencer. 1995. Effects of selective logging on soil characteristics and growth of planted dipterocarp seedlings in Sabah. In: R.B. Primack and T.E. Lovejoy, editors. Ecology, Conservation, and Management of Southeast Asia Rainforests. Yale University Press, New Haven, Connecticut, USA.

Pinard, M.A. and F.E. Putz. 1996. Retaining forest biomass by reducing logging damage. Biotropica 28.

Pinard, M.A., F.E. Putz., J. Tay, and T.E. Sullivan. 1995. Creating timber harvest guidelines for a reduced-impact logging project in Malaysia. Journal of Forestry 93:41-45.

Putz, F.E. 1994. Approaches to Sustainable Forest Management. CIFOR Working Paper No. 4.

Putz, F.E. 1996. A brief introduction to statistics and experimental design (unpublished lecture notes). 
Putz, F.E. 1996. Matrix-based population projection: an introduction. (unpublished lecture notes).

Putz, F.E. 1996. MINITAB: getting started (unpublished lecture notes).

Sist, P. 1996. Basic information on the STREK permanent sample plots for statistical data analysis (unpublished lecture notes).

Sist, P. 1996. Reduced-impact logging trials in East Kalimantan (STREK Project): harvesting volumes and damage assessment. (unpublished).

Sist, P. and N. Nguyen. 1996. The CIRAD-Forêt approach to growth and yield database management (unpublished).

Zulkifli Yusop and Anhar Suki. 1994. Effects of selective logging methods on suspended solids concentration and turbidity level in stream-water. Journal of Tropical Forest Science 7:199-219. 
About this volume. This publication is a collection of papers which were prepared in connection with CIFOR's first International Training Seminar on Reduced-Impact Timber Harvesting and Natural Forest Management. The seminar was held in Bogor (West Java) and at a field site near Balikpapan (East Kalimantan), Indonesia from July 14-27, 1996. Throughout the workshop, field exercises were integrated with classroom activities. As a final exercise each participant was required to conceive, plan, and conduct an individual, one-day experiment on a research question related to logging impacts or to a related issue of importance in the management of natural forests in the tropics. Each participant then wrote a brief report describing the hypothesis, the research design, the statistical tests used, and the results of the investigation. These reports were used as the basis for oral presentations given by the participants, and are reproduced here in the hope that they will promote the use of rigorous experimental design and analysis in research relating to the management of natural forests in the tropics. In reading the papers it should be kept in mind that each research project was carried out in less than one day, with limited equipment, and using assistance only such as the participants could provide each other. The data analysis and write-up phases were also brief, but we hope that the reports are indicative of the hard work and creative energy brought to the workshop by the participants. Altogether, we believe this was an excellent workshop, and that the participants carried away with them some of the enthusiasm for research, and its potential for solving problems in tropical forestry, which characterises the work being undertaken at CIFOR. We look forward to additional workshops of this type in the future.

About CIFOR. The Center for International Forestry Research was established in 1993 under the Consultative Group on International Agricultural Research (CGIAR) in response to global concerns about the social, environmental, and economic consequences of loss and degradation of forests. CIFOR's Mission is to contribute to the sustained well-being of people in developing countries, particularly in the tropics, through collaborative strategic and applied research and related activities in forest systems and forestry, and by promoting the transfer of appropriate new technologies and adoption of new methods of social organization, for national development. 